\title{
Kamuda Geleneksel İntranetten Dijital Çalışma Ortamına Geçiş: TÜIK İntranet Başarı Hikâyesi
}

\author{
Furkan METIN*
}

\begin{abstract}
Öz
Bilgi, kamu örgütleri açısından stratejik bir öneme sahip midir? Kamu yöneticilerinin tamamına yakını bu soruya evet yanıtını verecektir. Lakin etkin ve verimli bir biçimde kullanılan yazılı kurumsal hafızaya sahip bir kamu kurumu görebilmek neredeyse imkânsız. Yazılı hale getirilemeyen veya yazılı hale getirilse dahi kișisel bilgisayarlarda hapsolan bilgi notu, sunum, tutanak veya rapor gibi "değerli" bilgiler, çalıșanların kurumlardan ayrılması ile birlikte adeta buharlaşıp gitmektedir. Bu vaka çalıșmasında süratle dijitalleșmekte olan çalıșma ortamlarında, bireyler ve birimler arası etkin ve verimli bir örgütsel e-ișbirliği için yeni nesil sosyal İntranet sistemlerine duyulan yüksek gereksinime değinilecektir. Bu kapsamda iș hayatında e-dönüșüm zaruretinin en erken farkına varan kamu kurumlarından biri olan Türkiye İstatistik Kurumu'nda 20122017 yılları arasında gerçekleşen İntranet devrimi detaylı bir biçimde incelenecektir. Dijital İntranet sistemleri ile birlikte (a) çalışanların zaman ve mekândan bağımsız olarak e-işbirliği yapabilmesi, (b) iletişim maliyetlerinin düşürülmesi, (c) kurumsal bilişim sistemlerinin İntranet ile entegre edilmesi ve (d) yazılı kurumsal hafiza oluşumunun tohumlarının atılması, gibi süreçlerin nasıl tesis edildiği açıklanmaya çalışılacaktır. Bu çalıșma niteliksel bir araștırma olup, veriler gözlem, görüșme ve belge toplama tekniği ile toplanmıștır. Bu çalıșma örgütsel e-ișbirliği ve sanal uygulama topluluğu yaklaşımlarının Türk Kamu sektöründe hayata geçirilmiş ilk uygulama numunelerinden birini teșkil etmektedir.
\end{abstract}

Anahtar Kelimeler: İntranet, Dijital İşyeri, Kamu, E-İşbirliği, Sanal Uygulama Toplulukları.

\section{Moving from Traditional Intranet to Digital Workplace in Public Sector: The Success Story of TurkStat Intranet}

\section{Abstract}

Is knowledge considered as a valuable asset in public sector? Most of the answers of top public managers would be yes to this question; however it is quite rare to see a public organisation which has a collaborative digital knowledge management platform. Both the knowledge in unwritten formats such as individual's memories and also the knowledge in written forms are locked up in personal computers such as fact sheets,

Geliş/Received: 27.08 .2018

Kabul/Accepted: 01.03.2019

DOI: http://dx.doi.org/10.17336/igusbd.454110

* TÜIK Uzmanı, Türkiye İstatistik Kurumu, Bilişim Teknolojileri Daire Başkanlığı, Ankara, Türkiye, E-posta: furkanmetin@gmail.com, ORCID ID https://orcid.org/0000-0001-5782-6581 
reports and presentations. Therefore, the organisational knowledge is disappeared in the case of public employee turnover. In this case study, the need of contemporary digital Intranet systems with virtual communities of practices in order to have an effective organisational e-collaboration in today's highly virtualisation on working life is underlined. In this regard, the Intranet revaluation of Turkish Statistical Institute, which is one of the first public institutions about identifying the need of e-transformation in the work life, between the years 2012 and 2017 will be investigated in details. Meanwhile, how several beneficial outcomes obtained such as (a) enabling e-collaboration among employees regardless of their location and department, (b) decreasing the cost of organisational communication, (c) integrating organisational software applications and, (d) laying the foundation of participative written organisational memory, will be further explained in this article. In this article the qualitative research approach was adopted and the data collected by observation, interview and document collection techniques. This paper is one of the first studies in which organisational e-collaboration and virtual communities of practice approaches were implemented in a Turkish public sector organisation.

Keywords: Intranet, Digital Workplace, Public Sector, E-Collaboration, Virtual Communities of Practice.

\section{Giriş}

Dördüncü Endüstri Devrimi'nin arifesinde bulunduğumuz bu yıllarda, bilgi ve iletişim teknolojilerinde yaşanan gelişmelere paralel olarak çalışma ortamları da hızla dijitalleşmektedir. Çalışma ortamlarının dijitalleşme hızını ise büyük ölçüde bireysel İnternet kullanım oranı belirlemektedir. Türkiye İstatistik Kurumu verilerine göre 2009 yılında \%30 seviyelerinde olan geniş bant İnternet erişimi olan hanelerin oranı 2018 yılı itibari ile \%82.5 seviyesine çıkmıştır. Diğer bir ifade ile Ülkemizde her beş haneden dördünde hızlı İnternet erişimi bulunmaktadır. İnternet kullanan 16-74 yaş grubundaki bireylerin yaklaşık \%45'i e-Devlet hizmetlerini kullandığını belirtirken, bu bireylerin \%30'unun ise İnternet üzerinden alış-veriş yaptığı belirlenmiştir (TÜIK, 2018). Bu veriler ışığında, gerek kamu örgütlerinin gerek ise özel sektör örgütlerinin İnternet üzerinden sunmakta oldukları hizmetlere yönelik muazzam bir arz/talep olduğu görülmektedir.

Son yıllarda İnternet erişimi olan cihaz ve birey sayısındaki artış ile birlikte dijital ortamda üretilen bilgi miktarı da muazzam bir ivme ile artış göstermektedir. İnternet üzerinde üretilen yapısal olmayan veri miktarının 2020 yılında, 2009 yılına kıyasla 44 kat artacağı öngörülmektedir. Her bir dakika içerisinde; YouTube platformuna 48 saat uzunluğunda video yüklenirken, aynı süre zarfında 35.000 civarında Facebook beğenisi yapılmaktadır. Bugün itibari ile İnternet'te yer alan 200 milyon civarındaki HD filmleri izlemek isteyen bir bireyin, aralıksız olarak 47 yll video izlemesi gerekmektedir. Günde 5 milyar kişi, telefon araması, mesajlaşma, tweet atma ve akıllı telefonlarındaki tarayıcılardan İnternet'te sörf yaparak, dijital ortamda 2.7 Zettabayt'a ulaşan veri yığınına katkıda bulunmaktadır (WATERFORD TECHNOLOGIES, 2017). Bireylerin ürettikleri verilerin yanı sıra sensor, GPS, sistem logları ile görüntü ve ses dosyaları gibi elektronik cihazlar tarafından üretilen veriler de ele alındığında İnternet ortamında adeta bir "bilgi çöplüğü", diğer bir ifade ile "büyük veri" ile karşı karşıya kalınmaktadır.

Tüm bu verilerin işlenerek, madencilik veya geri dönüşüm misali içlerinden değerli bilgilerin süzülmesi neticesinde bireylerin tüketim alışkanlıkları, karakter yapıları, inançları, sağlık durumları, seyahat bilgileri, aile ve arkadaş bağları, iş ve eğitim hayatlarına dair birçok bilgi bir araya getirilmektedir. Bireylere ait "değerli" bilgilerin bir 
araya getirilerek yapay zekâ sistemleri ile muhakeme edilmesi neticesinde ise; kişiye özel seyahat, alış-veriş, sağlık, kitap, film, yemek veya yol-rota vb. önerileri içeren ticari ürünler ortaya çıkmaktadır. Bunların yanı sıra güvenlik hususları öne sürülerek kişisel telefon görüşmeleri, sosyal medya hesapları ve GPS verileri takibe alınmakta ve bireysel izleme sistemleri hayata geçirilmektedir. Dördüncü Endüstri Devrimi'nin olgunlaşması ile birlikte büyük veri, veri madenciliği, yapay zekâ, nesnelerin İnterneti, makine öğrenmesi ve elektronik denetim gibi kavramlar daha sık duyulmaya başlanacaktır.

İnternet dünyasında bu gelişmeler yaşanırken, örgütler de dış çevrelerinde meydana gelen teknolojik değişimlerden etkilenmektedir. Dijitalleşme ile birlikte geleneksel iş süreçleri, örgütsel iletişim biçimleri ve çalışma alanlarına sanal boyutlar eklenmektedir (Metin \& Medeni, 2016). Bu dönüşüm neticesinde geleneksel İntranet sistemleri de hızla yerlerini dijital İntranet sistemlerine bırakmaktadır. İnternet, dünya genelinde bilgisayarların birbirleri ile haberleșmesini sağlayan iletişim ağı iken; İntranet, sadece bir örgüt içerisindeki bilgisayarların birbirleri ile iletişimini olanaklı kılan özel iletişim ağıdır (Aziz \& Dicle, 2017).

Geleneksel İntranet sistemlerinde genel itibari ile hiyerarşik bir onay sürecinden geçen bilgi ve belgeler çalışanlar ile paylaşılmaktadır. İletişim örgüt tarafından tek merkezden ve tek yönlü olarak yapılmaktadır. Dolayısı ile çalışanlar sadece örgüt içi iletişimin pasif (alıcı) kısmını oluşturmaktadır. $\mathrm{Bu}$ nedenle geleneksel İntranet sistemlerinde çalışanlar arası yatay iletişim ve işbirliği imkânları mevcut değildir. Öte yandan yeni nesil sosyal İntranet sistemleri (a) mesafeden bağımsız olarak çalışanlar arasında ortak doküman üzerinde çalışabilme, (b) forumlarda tartışma yapabilme, (c) vikiler olușturabilme, (d) kurumsal uygulamalara yetkiler bazında erișim sağlama ve (e) anlık sohbet gibi bir birinden farklı elektronik işbirliği (e-işbirliği) gibi imkânlar sunmaktadır. Yeni nesil sosyal İntranet sistemlerinde; benzer görev veya ilgi alanına sahip çalışanlar dijital ortamlarda bir araya gelerek, Linkedin, Facebook ve Whatsapp gibi sosyal medya platformu gruplarında olduğu gibi, gruplar oluşturabilmektedir. Sosyal İntranet gruplarında yapılan paylașımlar, bu gruplara üye olan çalışanların etkinlik akışlarında otomatik olarak görüntülenmektedir.

$\mathrm{Ne}$ var ki, geleneksel İntranet sistemlerinden, dijital İntranet sistemlerine geçiş̧ süreci çeşitli nedenlerden ötürü sancılı olabilmektedir. Dijitalleşmenin maddi getirileri göz önüne alındığında kar amacı güden örgütler bu dönüşüm için daha istekli olurken, kamu örgütlerinde değişime karşı direnç daha yüksek olmaktadır. Üst yönetim desteğinin sağlanması, bir dijital dönüşüm stratejisinin oluşturulması, gerekli bütçenin ayrılması, mevzuat düzenlemesi, teknik alt yapının hazırlanması, mevcut bilişim uygulamaları ile entegrasyon ve çalışanların bilgilendirilmesi/eğitilmesi gibi birbirinden farklı faktörlerin sağlıklı bir biçimde yönetilebilmesi gerekmektedir. TÜİK İntranet'i Başarılı Kılan Unsurlar başlı̆̆ı başta olmak üzere çalışmanın ilerleyen bölümlerinde tüm bu faktörlerin nasıl bir arada yönetilebildiği detaylı bir biçimde açılanacaktır.

$\mathrm{Bu}$ çalışmanın birinci bölümünde BİT yaşanan gelişmeler neticesinde bilgi toplumlarında süratle sanallaşmakta olan iş hayatına ve bu iş hayatı içerisinde etkin ve verimli bir örgütsel e-işbirliği için kamu örgütlerince sanal uygulama topluluklarına duyulan gereksinime değinilecektir. Çalışmanın ikinci bölümünde ise Türkiye İstatistik Kurumu (TÜİK) İntranet sisteminde 2014-2017 yılları arasında gerçekleştirilen devrim niteliğindeki çalışmalardan bahsedilecektir. Bahsi geçen yıllar arasında 1990'lı yılların statik html teknolojisine sahip, birimlerin bilgi, belge paylaşımı, duyuru yapma gibi hususlarda Bilgi İșlem Dairesi'ne bağımlı olduğu, kișiler arası bilgi paylașımına ve birlikte çalışmaya olanak sağlayamayan tek yönlü iletişimin hâkim olduğu Eski TÜIK İntranet sisteminden; bunların tamamının ve daha fazlasının mümkün kılındığı Yeni TÜi̇K İntranet Platformu'na geçiş süresince gerçekleştirilen çalışmalara değinilecektir. 
Niteliksel bir vaka araştırması olan bu çalışmada kullanılan veriler gözlem, görüşme ve belge toplama tekniği ile derlenmiștir. Bu çalıșma örgütsel e-işbirliği ve sanal uygulama topluluğu yaklaşımlarının Türk Kamu sektöründe hayata geçirilmiş ilk uygulamalarından birisi olması hasebi önem arz etmektedir. Diğer yandan çalışma bulguları hususen dijital İntranet sistemlerine geçiş yapmak isteyen kamu örgütleri için yol gösterici mahiyettedir.

\section{2. İş Hayatında e-Dönüşüm ve e-İşbirliği 2.1. İş Hayatında e-Dönüşüm}

Çalıșma hayatında esnekliğin sağlanmasında İnternet teknolojilerinde vuku bulan gelişmelerin yanı sıra yeni nesil İnternet tabanlı iletişim araçlarının da şüphesiz önemli bir tesiri olmuştur. Günümüzden çok değil, belki yirmi yıl kadar önce iş yaşamında henüz yaygın olmayan İnternet'e sahip kişisel bilgisayarlar, ortak yazıcılar, e-posta sistemleri, video konferans sistemleri, akıllı telefonlar, forumlar ve vikiler gibi BíT sistemleri günümüz ofislerinin vazgeçilmez iş araçları olmuştur. Kullanılan İnternet tabanlı iletişim cihazları ve platformları nihai noktada adeta çalışanların ofisi mahiyetine bürünmektedir (Meister \& Willyerd, 2010).

Teknolojinin çalışma hayatında yol açtığı diğer iki önemli değişim, sanal örgüt arkadaşları ve sanal ekip arkadaşları kavramlarının ortaya çıkması olarak gösterilmektedir (Johns \& Gratton, 2013). Çalışma ortamının fiziksel ortamlardan, İnternet tabanlı iletişim cihazları üzerinden oluşturulan sanal ortamlara doğru geçirmekte olduğu dönüşüm neticesinde, çalışanların birbirlerini yüz yüze gördükleri ofis ortamları yerlerini, sesli postalar, e-posta grupları ve forum gibi elektronik iletişim araçları üzerinden yapılan sanal iş ortamlarına bırakmaktadır.

İnternet üzerinden ofislere uzaktan erişim imkânı sağlayan özel çalışma ağları (VPN) teknolojisi ile çalışanlar iş yerinde bulunmadan kurumsal bilişim sistemlerine erișim ve diğer çalışanlar ile sanal ortamda işbirliği yapabilme imkânı bulabilmektedir. Bu kapsamda örgütsel faaliyetlerin yer ve zamandan bağımsız bir biçimde elektronik ortamlar üzerinden işbirliği içerisinde yürütülmesi yaklaşımı üzerine bina edilen sanal uygulama toplulukları yaklaşımı son yıllarda iş hayatında süratle yaygınlașma göstermektedir.

\section{2. e-İşbirliği ve Sanal Uygulama Toplulukları}

Lave ve Wenger (1991) uygulama topluluğu kavramını; belirli tutkuları ve ilgi alanlarını paylaşan bir grup bireyin bu alandaki mevcut tecrübelerini artırmak maksadı ile oluşturduğu topluluk olarak ifade etmiștir. Sanal uygulama toplulukları (SUT) ise uygulama topluluğu üyelerinin fiziksel ortamlar yerine elektronik (sanal) ortamlarda bir araya gelerek iletişim kurdukları ve bilgi paylașımı gerçekleștirdikleri gruplar olarak tanımlanabilir (Faraj, Kudaravalli ve Wasko, 2015). Whatsapp, Viber, Bip gibi çevrimiçi sohbet grupları, e-posta grupları, Facebook gibi sosyal paylaşım sitelerinde yer alan gruplar, kurumsal İntranetler ve forumlar SUT için verilebilecek bazı güncel örneklerdir.

Nonaka (1991) kişisel bilgilerin diğer bireylerin erişimine sunulabilmesini, bilgi üreten organizasyonların en temel aktivitesi olarak tanımlanmaktadır. SUT ile kişisel bilgiler örgüt üyelerinin kullanımına açılmaktadır. SUT üyeleri arasında gerçekleştirilen bilgi mübadeleleri neticesinde ortak dil oluşumu, iyi uygulama örneklerine erişim, örgütsel yazılı hafıza oluşumu, örgüt içerisinde topluluk bilincinin geliştirilmesi, bireysel yeteneklerin gelişimi gibi faydalar elde edilebilmektedir (Saint-Onge ve Wallace, 2003). Gelișen BİT neticesinde uygulama topluluklarının, sanal uygulama topluluklarına 
dönüşmesi ile birlikte topluluk üyeleri arasında gerçekleșen tecrübe paylaşımının mahiyeti de iletişim biçimi bağlamında dönüşüm geçirmektedir.

Sanal uygulama topluluklarında İnternet tabanlı iletişim araçları üzerinden yapılan iletişimin biçimi de geleneksel iletişim biçimlerine nazaran farklılıklar barındırmaktadır. Geleneksel görüşme olarak da tabir edilen, aynı fiziksel mekânda ve eș zamanlı (senkron) iletişim kurma biçimi olan yüz yüze iletişim ve diğer yandan farklı fiziksel ortamlarda ve eş zamanlı olarak iletişim kurma biçimi olan telefon görüşmeleri sanal uygulama topluluklarında yerlerini Şekil 1. içerisinde görüldüğü üzere İnternet tabanlı teknolojilerin yaygınlaşması ile sanal ortamlarda ve eşzamansız (asenkron) iletişim biçimlerine bırakmaktadır (Saint-Onge \& Wallace, 2003).

Şekil 1. Sanal ortamlarda işbirliği

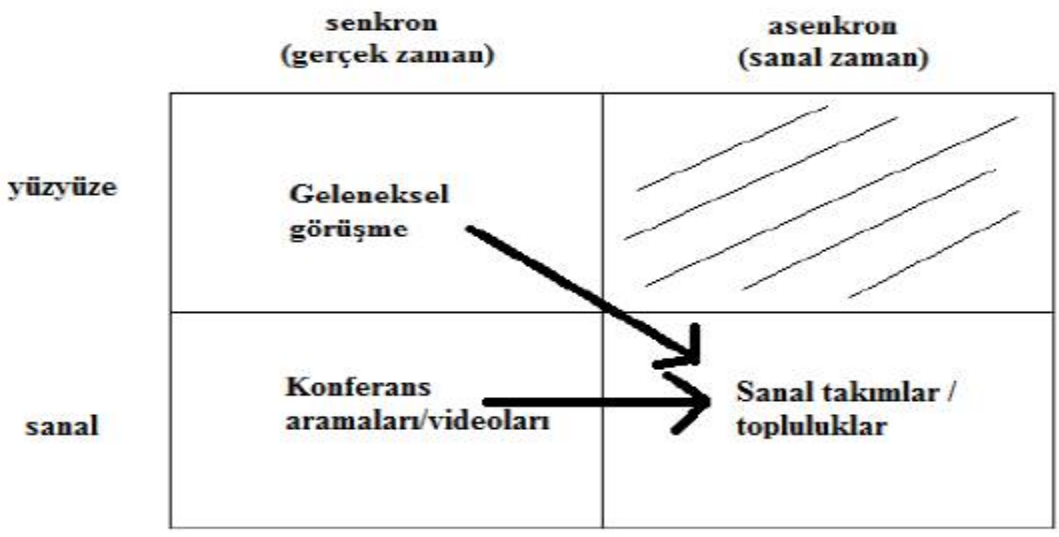

Kaynak: Metin ve Medeni (2016, s.131)

Böylece çalışanlar mekân ve zamandan bağımsız olarak aynı yerel ağa veya İnternet'e bağlı olarak birbirleri ile işbirliği yapabilme imkânına kavuşmaktadır. Mekândan bağımsızlık özellikle aynı örgütün farklı ilçe, şehir veya ülke gibi coğrafi yerleşkelerde yer alan birimlerinde çalışan kişiler arasında işbirliğinin etkin bir biçimde yürütülebilmesi için önem teşkil etmektedir. Hususen coğrafi açıdan farklı saat dilimlerinde çalıșan kișilerin eş zamanlı iletişim kurabilmesi çok daha zor olabilmektedir (Dube, Bourhis, \& Jacob, 2006). Örneğin Türkiye'de öğle saatleri yaşanırken, Japonya'da gece yarısı yaşanmaktadır. Bu nedenle Türkiye'de ki bir çalışanın Japonya'da ki bir diğer çalışan ile eş zamanlı iletişim kurabilmesi ülkeler arasındaki saat farkından ötürü oldukça zordur. Bu noktada SUT eş zamansız (asenkron) iletişime olanak sağlayarak sanal ortamda örgütsel işbirliğini olanaklı kılmaktadır.

Örgütler içerisinde var olan SUT üyeliği, genel itibari ile örgüt içi iletişim ağına (LAN, VLAN) bağlı olan herkese açıktır. Örgütsel bir SUT’a katılım isteğe bağlı, teşvik edilen veya zorunlu olmak üzere çeşitli biçimlerde olabilir. Lakin genel itibari ile çalışanların bir SUT'a katılım veya ayrılma kararları gönüllülük esasına bağlı olmaktadır. Bireysel gönüllük ise çalışanların kendilerinin ve/veya meslektaşlarının SUT platformlarındaki bilgi paylaşımları neticesinde elde edecekleri faydaya bağlı olmaktadır (Dube vd., 2010).

Bir örgüt içerisindeki SUT örgütsel ve bireysel ihtiyaçlara bağlı olarak şekillenebilir. SUT örgütsel faaliyetlerin yürütülmesi maksadı ile örneğin örgütsel mali 
işlerin yürütüldüğü bir merkez birimi ile diğer birimler arasındaki mali konulardaki işbirliğinin sanal ortamda sağlanması maksadı ile kurulabilir. Bu bağlamda mali işlemler ile ilgili duyurular ve talimatlar merkez birim tarafından forum üzerinden diğer birimlerde çalıșan SUT üyesi kişiler ile paylașılabilir. Bir SUT üyesi tarafından sorulan bir soruya ilgili SUT üyelerinin tamamı, örgütsel hiyerarşilerine bağlı olmaksızın muhatap olmaktadır. SUT platformları aracılığı ile üyeler arasında yatay iletişimin şeffaf bir biçimde olanaklı kılınmasıyla; ortak bir sorun durumunda her bireyin ayrı ayrı çözüm aramasının önüne geçilmekte, bir konu hakkındaki soruların tekrar tekrar sorulması ve cevaplanması asgari düzeye çekilmekte, ayrıca SUT üyeleri arasında beyin firtınası yapılabilmesinin ve yeni bilgi üretiminin de önü açılmaktadır.

Diğer yandan bir örgüt içerisinde, doğrudan örgütsel faaliyetler ile ilgili olmayan, örgüt üyelerinin farklı konularda ilgi alanlarına giren konularda da SUT oluşturulabilmektedir. Örneğin resim sanatına ilgi duyan çalışanlarca resim etkinlikleri vb. adı altında bir SUT oluşturularak, örgüt içerisindeki sanatseverlerin bu sanal topluluğa katılımları sağlanabilmektedir. Böylece çalışanlar aynı örgüt içerisinde ortak kişisel ilgi alanlarına sahip kişiler ile sanal ortamda tanışabilmekte ve bu kişiler ile tecrübe paylaşımı yapabilmektedir.

Bunların yanı sıra çoğu zaman çalışanlar arasında yaşanan etkileşimler neticesinde ortaya çıkan yeni fikirlerin mülkiyeti yöneticilerce sahiplenilmektedir. Lakin SUT üyeleri arasında işbirliğinin ve bilgi paylaşımlarının elektronik ortamlarda yapılması neticesinde hangi çalıșanın, ne zaman, hangi konuda ilgili çalıșmaya ne tür bir katkı sunduğu da kaydedilmektedir. Böylece örgütsel faaliyetler ile ilgili bir konuda değerli katkılar sunan çalışanların fikri paylaşımları bir nevi güvence altına alınmaktadır.

\subsection{Kamu Örgütleri Açısından Sanal Uygulama Topluluklarının Önemi}

Sanal uygulama toplulukları (SUT) ile örgütler çalışanları arasındaki etkileşimi ve bilgi mübadelesini hızlandırarak, örgütsel bilgi sermayesinin artmasını sağlayabilirler. SUT'da yapılan iyi uygulama örneklerine yönelik paylaşımlar, diğer çalışanlar açısından ufuk açıcı olabilmektedir. Belirli bir konuda daha önce oldukça fazla emek ve zaman harcanarak ulaşılan bir çözüm, bir başka örgüt çalışanın karşılaştığı benzer bir sorunun bir kaç dakika içerisinde çözülmesine yardımcı olarak hayat kurtarıcı olabilir (Saint-Onge \& Wallace, 2003).

SUT'ların bilgi örgütleri açısından bahsi geçen nedenlerden ötürü öneminin gün geçtikçe artması, Türkiye'de SUT yaklaşımlarının sınırlı kalması konusundaki nedenlerin anlaşılmasını ve bu sorunların giderilmesine yönelik politikalar geliştirilmesini zorunlu kılmaktadır. Türkiye' de esnek çalışma uygulamalarında bahsi geçen kısıtlamalara rağmen iş süreçlerinin elektronikleşmesi neticesinde kamu örgütlerinde de neredeyse tüm birimlerin iș süreçleri, bilişim birimlerine ait iş süreçleri ile kesişir hale gelmiștir. Diğer bir ifade ile günümüzde günlük iş süreçlerinin yürütülmesi için bilişim sistemlerini kullanmayan kamu birime rastlamak oldukça güçtür. Dolayısıyla her ne kadar kar amacı gütmese dahi kamu örgütleri tarafından sunulan özellikle bilgi yoğun ürünlerin özel sektör tarafından sunulabilmesi ihtimali, özellikle bilgi üreten kamu örgütlerinin varlık nedenlerinin yakın gelecekte sorgulanmasına yol açabilir.

Bu hususta yakın gelecek için verilebilecek muhtemel bir senaryo örneği olarak büyük veri çalıșmaları üzerinden günlük enflasyon hesaplama gösterilebilir. Teknolojik gelişmeler, İnternet üzerinden alış-veriş hacminin artması, özel șirketlerin stok ve satışlar ile ilgili olarak olușturdukları veri bankaları göz önünde bulundurulduğunda gerek web, gerek ise ilişkisel veri tabanı ortamlarında tutulan elektronik veri hacmi muazzam bir ivme ile artmaktadır. Yakın gelecekte özel şirketlerin, web servisleri gibi gelişmiş bilişim teknolojileri ile anlık ulaşabilecekleri veri kitleleri ile milyonluk örneklem hacimleri 
oluşturarak ülke genelinde kamu sektöründe hesaplanan rakamlardan çok daha gerçekçi günlük enflasyon rakamları açıklayabilecek kapasiteye ulaşmaları pek de imkânsız bir olasılık değildir. Örneğin, Harvard Üniversitesi doktora öğrencisi Alberto Cavallo tarafından 2007 yılında hazırlanan PriceStats* yazılım uygulaması ile İnternet siteleri ve toptan satış mağazaları verilerinden elde edilen büyük veri üzerinden 22 ülke için enflasyon hesabı yapılmaktadır. The Economist Dergisi tarafından 2012 yılından itibaren Arjantin Devleti tarafından hesaplanan enflasyon rakamları yerine PriceStats verilerini kullanacağını açıklanmıştır (Erbay \& Kör, 2016). Bu durum Ulusal İstatistik Ofislerinin sınırlı miktarda veri evreni kullanarak açıkladıkları enflasyon rakamlarının çok yakın gelecekte sadece kâğıt üzerinde kalmasına ve bu rakamların reel hesaplamalarda göz ardı edilmesine neden olabilir. Bu ve benzer durumlar kimi kamu kurumlarının varlıklarının veya ürettikleri ürünlerin özellikle Endüstri 4.0 ile birlikte daha da ciddi manada sorgulanmasına yol açabilecektir.

Bu çalışmanın üçüncü bölümünde de detaylı bir biçimde incelenecek olan TÜiK İntranet platformu, yeni nesil e-işbirliği ve sanal uygulama topluluğu yaklaşımlarının Türk Kamu sektöründe hayata geçirilmiş başarılı bir numunesini teşkil etmektedir.

\section{TÜİK İntranet Başarı Hikâyesi}

İnternet, dünya genelinde bilgisayarların birbirleri ile haberleşmesini sağlayan iletişim ağı iken; İntranet, sadece bir örgüt içerisindeki bilgisayarların birbirleri ile iletişimini olanaklı kılan özel iletişim ağıdır. Türkiye'deki kamu kurumlarının geneline hâkim olan html tabanlı statik İntranet sitelerinde sayfa içerikleri dinamik olarak güncellenememekte ve her daim İntranet sunucularına erişim yetkisine sahip ve html kodlaması bilen kişilere ihtiyaç duyulmaktadır. Diğer yandan statik html teknolojisi haricinde kullanılan asp.net, Java ve php gibi dinamik web kodlama dilleri ile geliștirilen İntranet sistemlerinde son kullanıcıların herhangi bir kodlama bilgisine sahip olmadan, hızlı bir biçimde içerik güncellemesi yapabilmeleri sağlanabilmektedir. İçerik yönetimi yapan çalıșanlar kendileri için hazırlanan yönetici ekranlarından İntranet sitelerinin içeriklerini güncelleyebilmektedir.

Ne var ki, kullanılan web programlama dili ne olursa olsun, neredeyse tüm kamu kurumlarında kullanılan İntranet sistemlerinde, iletilerin bir veya bir kaç merkezi kaynaktan tek yönlü olarak pasif bir biçimde bekleyen alıcılara gönderildiği tek yönlü iletişim biçimi kullanılmaktadır. Tek yönlü iletişim modellerinin esas alındığı İntranet sistemlerinde çalıșanların içerik yayınlama gibi bir imkânları bulunmamaktadır. Çalışanlar adeta işitebilen ancak konuşamayan bireyler vaziyetine bürünmektedir. Dolayısı ile kişisel bilgi ve tecrübelerin çalışanlar arasında mübadele edilmesi mümkün olamamaktadır.

Diğer yandan, iki yönlü iletişimde ise göndericilerin mesajlarını alan alıcılar, gönderici konumuna geçerek aldıkları mesaja yanıt verebilme imkânına sahiptir. Yeni nesil İntranet sistemlerine hâkim olan iki yönlü iletişim imkânı sayesinde, çalıșanlar arası yatay iletişim ve iş birliği olanaklı hale gelmektedir. Bu kapsamda TÜİK'te tek yönlü iletişime ve statik html teknolojisine sahip İntranet sistemi 2017 yllında bir kenara bırakılarak, iki yönlü iletişimin esas alındığı yeni nesil sosyal İntranet platformuna geçiş yapılmıştır. Bu yeni nesil İntranet platformu ile TÜİK çalışanları arasında iç iletişimin geliştirilmesi, bilgi paylaşılması, yeni bilgi üretilmesi ve çevrimiçi ortamda sürdürülebilir kurumsal hafıza oluşturulması hedeflenmektedir. 


\subsection{Kronolojik Olarak Atılan Adımlar}

TÜİK üst yönetimi tarafından elektronik ortamda kurumsal hafiza oluşturulması, birimler ve kişiler arası iletişimin etkin ve verimli bir hale getirilebilmesi maksadı ile 2012 yılında kurum için uygun olabilecek elektronik bilgi ve belge paylaşım ve yönetim platformlarının incelenmesi talimatı verilmiștir. Bir kaç yılı aşkın süren araștırma ve geliştirme çalışmaları neticesinde LifeRay, Alfresco ve eXo platformu ürünlerin incelenmiș ve nihai olarak 2014 yılında alternatifler arasından Kurum Üst Yönetimince eXo platformunun yeni TÜİK İntranet platformu olarak kullanılmasına karar verilmiștir.

\section{Sekil 2. Eski TÜİK İntranet Sistemi Ara Yüzü}

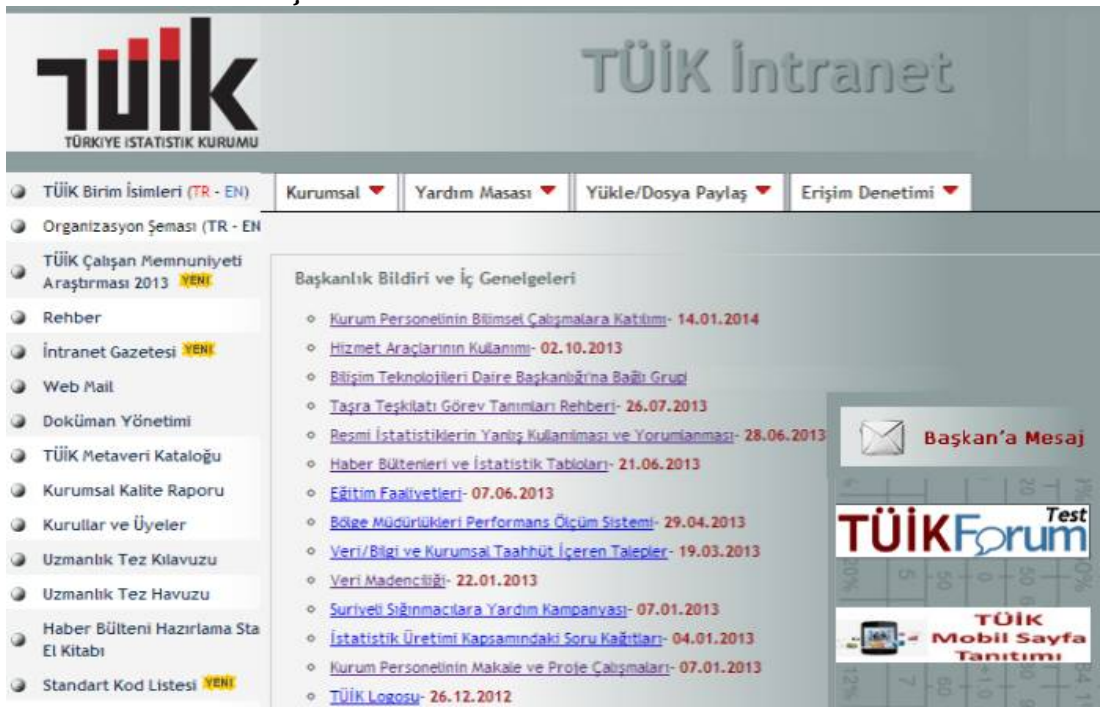

Bu karar üzerine 2014 ve 2016 yıllarında TÜİK İntranet sisteminde geçiş evresi yaşanmıștır. İki yıl süren geçiș evresinde kurum çalıșanlarınca hem eXo Platformu (TÜİK İntranet) hem de Eski TÜiK İntranet (bakınız Şekil 2.) sistemine erișim yapılabilmiştir. Geçiş evresi boyunca Eski TÜİK İntranet sistemi içerisinde yer alan bilgi ve belgelerin tasnifi yapılmıştır.

Tasnif edilen bilgi ve belgeler TÜİK İntranet platformuna (eXo Platform) aktarılmıştır. Bu zaman zarfında ayrıca Eski TÜİK İntranet içerisinde yer alan çeşitli yazılım uygulamalarına ait erişim adresleri de TÜİK İntranet içerisinde geliștirilen Sık Kullanılanlar (Şekil 4.) uygulamasına entegre edilmiştir. İntranet sistemindeki değişim aşamaları Tablo 1. içerisinde tarihsel olarak sıralanmıştır. 
Tablo 1. TÜİK İntranet Reformunda Atılan Adımlar

\begin{tabular}{|c|c|}
\hline Tarih & Atılan Adımlar \\
\hline $2012-2014$ & $\begin{array}{l}\text { LifeRay ve Alfresco İntranet platformlarının incelenmesi } \\
\text { Türkçe dil desteği sorunu ve çeșitli entegrasyon sorunları nedeni ile } \\
\text { platformların kabul görmemesi }\end{array}$ \\
\hline 2014 içinde & $\begin{array}{l}\text { Açık kaynak kodlu eXo Platformu ürününün satın alınması } \\
\text { eXo firmasından (Fransa) gelen danışmanlar ile teknik alt yapının (sunucu ve } \\
\text { veri tabanı mimarisi) kurulması }\end{array}$ \\
\hline 2015 Mayıs & $\begin{array}{l}\text { "Eski İntranet çıkarılan dersler / Yeni İntranet (eXo) için yapılması } \\
\text { gerekenler" resmi bilgi notu hazırlanması }\end{array}$ \\
\hline 2015 Haziran & Yeni İntranetin teste açılması \\
\hline 2015 Temmuz & $\begin{array}{l}\text { Üst Yönetim tarafından, İntranetin } 15 \text { Ekim } 2015 \text { 'de açılması talimatının } \\
\text { verilmesi }\end{array}$ \\
\hline 2015 Ağustos & Eski İntranet içeriğinin Yeni İntranet Platformuna aktarılması \\
\hline 2015 Eylül & $\begin{array}{l}\text { TÜİK Merkez birimlerine Yeni İntranet eğitimi verilmesi } \\
\text { TÜIK Bölge Müdürlüklerine video konferans yöntemi ile eğitim verilmesi }\end{array}$ \\
\hline 2015 Ekim & Yașanan teknik sorunlardan ötürü Yeni İntranet'in açılmasının ertelenmesi \\
\hline 2015 Kasım & “TÜIKK Çevrimiçi Bilgi Yönetim Taslak Yönergesi” hazırlanmıștır \\
\hline 2016 Ocak & $\begin{array}{l}\text { Yeni İntranet'in etkin bir biçimde kullanılabilmesi için belirlenen bilimsel } \\
\text { adımların uygulanması için Kurum Başkanı'na bilimsel çalıştay yapılması } \\
\text { önerisinin sunulması }\end{array}$ \\
\hline 2016 içinde & $\begin{array}{l}\text { Yardım masası forumları oluşturulması } \\
\text { Farklı konularda örnek Forum içerikleri oluşturulması } \\
\text { Bilimsel çalışmaların gerçekleștirilmesi } \\
\text { Sık kullanılanlar, Duyurular, Erişim Denetimi gibi kurumsal yazılımlar } \\
\text { geliștirilmesi }\end{array}$ \\
\hline 2017 Ocak & $\begin{array}{l}12 \text { sayfalık TÜİK İntranet Yönergesi'nin Başkanlık Olur'una sunulması } \\
\text { İntranet veri tabanı ve sunucu yedekleme sorunlarının giderilmesi } \\
\text { İntranet'in kullanıma açılması }\end{array}$ \\
\hline 2017 Mart & $\begin{array}{l}\text { Üst Yönetim tarafından Merkez ve Taşra Teşkilatı arasında ortak proje } \\
\text { yürüten birimlere ait e-posta gruplarının kapatılması ve e-bilgi } \\
\text { paylaşımlarının İntranet içerisinde yer alan Alanlar (SUT) üzerinden } \\
\text { yapılması kararının verilmesi }\end{array}$ \\
\hline 2017 içinde & $\begin{array}{l}\text { İntranet platformu teknik altyapı (sunucu mimarisi) ve uygulama } \\
\text { sürümlerinin yenilenmesi için eXo firmasından danışmanlık alınması } \\
\text { Yaşanan entegrasyon sorunlarının giderilmesi }\end{array}$ \\
\hline
\end{tabular}

\subsection{Planlamada Dikkat Edilmesi Gereken Hususlar}

Yeni nesil sosyal İntranet sistemleri ile kurum içi iletișim ve işbirliği biçimlerinin elektronik, şeffaf ve paylaşımcı ortamlara aktarılması için ilk etapta öngörülen zaman kısıtlarının oldukça üzerine çıkabilmektedir. Yönetici değişimleri, mevzuattan kaynaklı aksamalar, personel direnci, bütçe kısıtları ve beklenilmeyen teknik sıkıntılar gibi çeşitli unsurlar İntranet sistemlerinde bahsi geçen dönüşüm planlarını öteleyebilmektedir.

Tablo 1. içerisinde de görülebileceği üzere html tabanlı statik Eski TÜİK İntranet sisteminden, Yeni TÜIKK İntranet sistemine normal şartlar altında iki yıl sürmesi öngörülen geçiş aşaması 2012 yılında başlayıp, 2017 yılının sonuna kadar devam etmiştir. Dolayısı ile kurumsal İntranet sistemlerini modernize etmek niyetinde olan kamu kurumlarının öncelikli olarak kullanmayı planladıkları İntranet platformlarını, eğer kendileri bu platformları geliștirmeyecekler ise, mevcut durumda Türkiye'de kullanan kamu veya özel sektör kurumlarının olup olmadığını incelemeleri gerekmektedir. 


\subsubsection{Açık ve Kapalı Kaynak İntranet Sistemleri}

Yeni bir İntranet platformu tesis etmek isteyen kamu kurumlarının öncelikli olarak, bu platformun açık kaynak kodlu mu, yoksa kapalı kaynak kodlu mu olacağına karar vermeleri gerekmektedir. Açık kaynaklı uygulamaların kodları umuma açık bir biçimdedir ve bu kodlar herkes tarafından geliştirilmeye açıktır. Dolayısı ile örgütün bir firmaya doğrudan bağımlı olma durumu söz konusu değildir. Üstelik açık kaynak kodlu uygulamalara genel itibari ile İnternet üzerinden ücretsiz olarak ulaşılabilmektedir. Lakin her ne kadar açık kaynaklı uygulamalar ücretsiz olarak edinilebilse dahi bu uygulamaların kurumsal sistemlere entegrasyonu, isteğe bağlı özellikler eklenmesi ve oluşabilecek teknik aksaklıklarda tecrübeli bilişim uzmanlarının müdahalesi gibi maliyetler söz konusudur. Bu maliyetlerin karşılanması hususunda, büyük ölçekli bilișim birimleri olan kurumlarda mevcut bilişim uzmanı kaynaklarının kullanılması tercih edilebilir. Öte yandan yeterli düzeyde nitelikli bilișim uzmanı bulunmayan veya hususi olarak İntranet platformu için bilișim uzmanı tahsis etmek istemeyen kurumlar tarafından ise teknik destek hizmeti satın alma yoluna gidilebilir.

Kapalı kaynak kodlu uygulamalara ait kodlar, açık kaynaklılara zıt olarak, umuma açık bir biçimde bulunmaz. Bu uygulamalar hizmet sağlayıcı tarafından ücreti mukabilinde alınabilir. Kapalı kaynak kodlu uygulamaların açık kaynak kodlu uygulamalara kıyasla bazı dezavantajları bulunmaktadır. Burada dikkat edilmesi gereken hususlardan bir tanesi bilgi güvenliği ve firmaya karşı bağımlı hale gelme riskleridir. Çünkü kapalı kaynaklı uygulamalar içerisinde yer alan kodların ne biçimde çalışacakları bilinemeyebilmektedir. Diğer bir ifade ile kapalı kaynak uygulamaların kuruma ait bilgiler üzerinde tasarrufta bulunup bulunmadığının bilinmesi oldukça zordur. Bu durum bilgi güvenliği hususunda zafiyet meydana getirebilir. Bunların yanı sıra kapalı kaynak uygulamaları satın alan kurumlar, satın aldıkları uygulamaya ait kodlara müdahale etme imkânı bulunmadığı için ürün sağlayıcı firmaya karşı bağımlı hale gelmektedir. Kapalı kaynak kodlu uygulamaların diğer bir dezavantajı ise muadil açık kaynak kodlu uygulamalara nazaran oldukça yüksek fiyatlara sahip olmasıdır.

Tüm bu olumsuz yönlerinin yanı sıra kapalı kaynak kodlu uygulamalar ileri düzeyde testlere tabi tutulmuş olmaları nedeni ile daha az sorun çıkarmaktadır ve çıkabilecek her türlü sorunun çözümü yüklenici firma tarafından sağlanmaktadır. Dolayısı ile bu uygulamaların kurumsal entegrasyon sürecinde kurumsal insan kaynağı ihtiyacı asgari düzeyde olmaktadır (Çekiç ve Üstündağ, 2016).

Kapalı kaynak kodlu bir paket program olan Microsoft SharePoint uygulaması ile eXo platformu 3.000 kişi civarında bilgisayar kullanıcısı olan bir kuruma ortama yıllık maliyeti açısından mukayese edilirse; SharePoint'in yıllık maliyeti, 15.000 \$ yazılım lisans maliyeti, $150.000 \$$ kullanıc lisans maliyeti, 185.000 entegrasyon maliyeti ile birlikte toplamda yıllık 350.000\$'a kadar varabilmektedir (Hitchins, 2014). TÜİK tarafından tercih edilen eXo platformunun ise 3.000 kullanıcı için yıllık bakım maliyeti $50.000 \$$ ve 7 gün yerinde teknik destek maliyeti (7.000\$) olmak üzere toplam maliyeti 57.000\$ civarında gerçekleşmektedir. $\mathrm{Bu}$ rakamlar göz önünde bulundurulduğunda eXo Platformu, SharePoint'e kıyasla 6 kat daha düşük maliyete sahiptir. Bu bağlamda, TÜİK tarafından eXo platformuna 4 yıl içerisinde, birinci, ikinci, üçüncü ve dördüncü yıllık bakım anlaşmaları için yaklașık (45.000\$* 4 yıl) 180.000 \$ ve dört kez teknik danışman alımının yaklașık $(20.000$ \$4 yll) 80.000 olmak üzere toplamda 260.000 \$ harcanmıştır. Nihai olarak SharePoint seçeneğine gidilmemesi 4 ylllık toplam süreçte 1.200 .000 \$'lık lisans maliyeti yerine 260.000 \$ harcanılarak, 1 milyon \$'lık bir tasarrufu da beraberinde getirmiştir. 


\subsubsection{Teknik Altyapı}

Mali boyutunun yanı sıra, kurumların eXo platformu ile ilgili olarak dikkat etmesi gereken unsurlardan bir diğeri bu platformun nevi şahsına münhasır davranışlarıdır. Hizmet anlaşması yapılmadan ücretsiz olarak github üzerinden indirilebilen platform açık kaynak kodlu Postgres veri tabanında ve Tomcat uygulama sunucusunda çalıştırılabilmektedir. Bu seçenekte platformun kullanımı esnasında yaşanabilecek sorunlara karşı yazılım kısmında ileri düzeyde Java programlama diline hâkim yazılımcı(lar), veri tabanı kısmında ise Postgres veri tabanı yöneticisi ve uygulama sunucusu ile ilgilenecek bir sistem yöneticisine ihtiyaç duyulmaktadır.

Teknik destek hizmetinin sunulduğu ücretli seçeneklerde ise 200 kullanıcıya kadar Profesyonel, 1.000 kullanıcıya kadar Kurumsal, sınırsız kullanıcı için Kurumsal Artı seçenekleri mevcuttur (eXo Platform Editions and Pricing, 2018). Kullanıcı sayılarına göre kullanılması gereken donanımlar değişim göstermektedir. Ortalama 4.000 kullanıcısı olan TÜIK'te, 26 GB Bellek-RAM ve 500 GB disk kapasitesine sahip, 8 çekirdekli bir adet bağımsız (standalone) sunucu bulunmaktadır. Ana sunucu haricinde İntranet içerisinde her türlü aramanın süratli bir biçimde yapılabilmesi için iki adet Elasticsearch arama sunucusu bulunmaktadır.

TÜİK bünyesinde, kullanıcı sayısı ve gelecekte artabilecek kullanım oranı göz önünde bulundurularak eXo platformu öncelikle birden fazla sunucunun eş zamanlı olarak hizmet verdiği kümeleme (cluster) mimarisinde tasarlanmıștı. Lakin eXo Platformu, her ne kadar şirket tarafından bu durum resmi olarak belirtilmese dahi, kümeleme sunucu mimarisi üzerinde sağlıklı çalışmamaktadır. Kümeleme mimari üzerinde çalışan sunucular arası verilerin eşlenmesi sürecinde yaşanan aksaklıklardan ötürü, bir sunucu üzerinden yapılan bir paylaşım farklı bir sunucu ile sisteme giren diğer çalışanlarca görülemeyebilmektedir. Bunların yanı sıra sunucuların kaynak kullanımları ve yük dengeleme aracının hassas ayarlamaları nedeni ile eXo platformu ancak bağımsız (standalone) sunucu mimarisinde sağlıklı bir biçimde çalışabilmektedir.

Bunların yanı sıra eXo platformu içerisinde forum bölümü ile belge ve dokümanlar bölümü içerisinde yer alan içerikler Java içerik yönetim teknolojisi olan JCR kullanılarak yapılmaktadır. Her türlü işlemde veri tabanına giderek işlem yapılması maliyetlerinin düşürülmesi ana fikri üzerine kurulu olan JCR-283 2009 yılında piyasaya sürülmüștür. Ancak hızla gelișen ve süratli bir biçimde çalıșan veri tabanı teknolojileri ve hızla yayılan Java tabanlı olmayan içerik yönetim sistemleri nedeni ile JCR artık genel geçer kabul gören bir standart olmaktan çıkmıştır. Adeta kapalı bir kutu hükmünde olan JCR içerisinde tutulan belgeler ve forumlara ait içeriklere müdahale edilme șansı bulunmamaktadır. Dolayısıyla ara yüzde yapılan değişikliklerin zaman zaman JCR'a yansımaması gibi durumlarda JCR'a müdahale edilememekte ve hatalı içerikler yönetilememektedir. JCR teknolojisinin günümüz içerik yönetim ihtiyaçlarına cevap veremediğinin farkında olan eXo Platform şirketi 2018 yılı Nisan ayında piyasaya çıan 5.0.0 sürümünde tüm indeks verileri, kullanıcı ayarları ve yönetici ayarları gibi daha önce JCR içerisinde tutulan verileri, veri tabanları içerisine aktarmıştır. Şirketin halen JCR içerisinde tutulan forum ve belge bölümü içeriklerini de gelecek sürümler içerisinde veri tabanlarına aktarma planları bulunmaktadır.

\subsection{TÜİK İntranet Platformunun Ana Bölümleri}

Yeni TÜİK İntranet platformu içerisinde Etkinlik Akışı, Alanlar, Forum, Viki, Belgeler ve Kişiler gibi eXo platformunun kurulması ile birlikte gelen temel öğeler bulunmaktadır. Bu öğeler ağırlıklı olarak Şekil 3.'de görüldüğü üzere sol menü içerisinde 
yer almaktadır ve bunlar ait detaylı bilgilendirmeler ilerleyen başlıklar altında yapılacaktır.

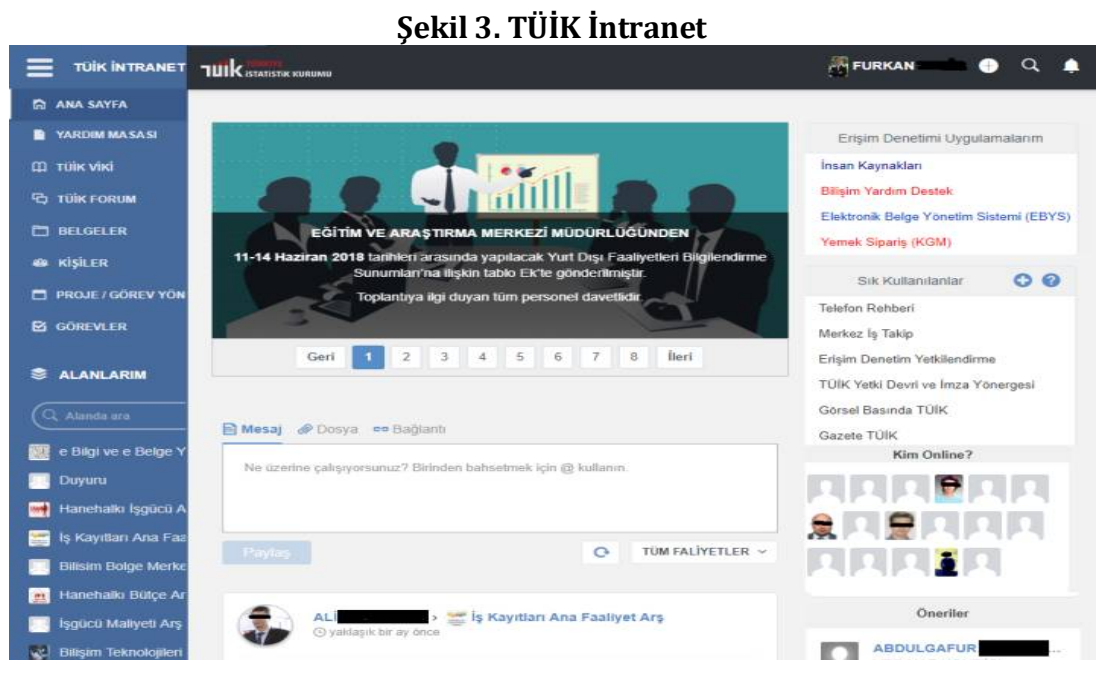

Burada vurgulanması gereken önemli bir unsur sol menüde yer alan Kişiler ve Alanlarım bölümleridir. Kurum çalışanları, kişiler bölümünden diğer kurum çalışanları ile bağlantı kurabilmektedir. Bir biri ile bağlantı kuran kişilerin yapmış oldukları paylaşımlar ise orta kısımdaki etkinlik akışında görüntülenmektedir.

$\mathrm{Bu}$ öğelerin haricinde kurum içerisinde ihtiyaç duyulan duyurular, erişim denetimi, sık kullanılanlar gibi çeşitli yazılım uygulamaları da TÜİK Bilişim Teknolojileri Daire Başkanlığı tarafından geliştirilerek İntranet içerisine entegre edilmiştir. Bu uygulamalar ağırlıklı olarak Şekil 3.'de görüldüğü üzere sağ bölüm iç̧erisinde sergilenmiştir. Bunların yanı sıra Şekil 3. içerisinde yer alan ana ekran görüntüsünde sergilendiği üzere sol menü içerisinde eXo platformu içerisinde yer alan viki, forum, belgeler ve kişiler gibi platformun temelini oluşturan varsayılan (default) uygulamalar yer almaktadır. Bu uygulamalara bir sonraki bölümden itibaren sırası ile değinilecektir.

\subsubsection{Alanlar}

Bu çalışmanın ilk bölümünde tanımı yapılan sanal uygulama topluluğu (SUT) kavramı, benzer tutku ve ilgi alanlarına sahip bireylerin gönüllülük esası ile sanal (elektronik) ortamlarda bir araya gelerek oluşturdukları topluluklardır. Günümüzde WhatsApp ve Facebook grupları ile Memurlar.net, Donanım Haber, Forum TR ve Kızlar Soruyor gibi forum platformları sanal uygulama topluluklarının en güncel örneklerini teșkil etmektedir. TÜíK İntranet içerisinde yer alan Alan (Space) bölümleri de tam olarak SUT tanımına tekabül etmektedir. Alan, belirli bir birim veya projeye dair ortak çalıșmalar yapacak kişiler tarafından oluşturulan, içerisinde kendine ait forum, viki, etkinlik akışı, dosya sunucusu bulunan, bir nevi TÜİK İntranet sisteminin küçük bir numunesini teşkil eden bölümlerdir.

TÜİK Genel Koordinasyon Toplantısı (GKT) - 2105 nolu karar üzerine TÜİK İntranet Alanlar bölümünde, istatistik üreten ve saha çalışmaları üzerinden veri derlenen çalışmalara ait 44 tane Alan oluşturulmuştur (Detaylar için lütfen Tablo 2.'ye bakınız). 
GKT kararı gereği veri toplama kapsamında yer alan tüm alan uygulamaları için TÜİK İntranet içerisinde bir Alan açılması kararlaştırılmıștır. Bu kapsamda açlan bir alanın yönetiminden Merkez Teşkilatında yer alan ilgili birimin, tüm alanların koordinasyonundan ise Veri Toplama ve Koordinasyon Dairesi (VTKD)'nin sorumlu olacağı belirtilmiştir.

Tablo 2. TÜİK İntranet İçerisinde Oluşturulan Alanlar (Sanal Uygulama Toplulukları)

\begin{tabular}{|l|l|l|l|}
\hline Alan Adı & İș Kayıtları Girișim & Sanayi Üretim & TÜFE Kira \\
\hline ADNKS Kurumsal & İş Sektörü Çevre & $\begin{array}{l}\text { Sektörel Enerji } \\
\text { Tük }\end{array}$ & Tüketici Eğilim \\
\hline Biyoteknoloji & İşyeri Eğilim & SGP & $\begin{array}{l}\text { Uluslararası Hiz. } \\
\text { Tic. }\end{array}$ \\
\hline Girișimlerde Bilișim & Katı Yakıtlar & Sinema ve Tiyatro & ÜFE \\
\hline GYKA Alanı & Kırmızı Et Üretim & Su Ürünleri & $\begin{array}{l}\text { Üniversite } \\
\text { Kütüphane }\end{array}$ \\
\hline Hane halkı Bilișim & Kurumsal Yerler & $\begin{array}{l}\text { Süt Toplama } \\
\text { Merkezi }\end{array}$ & $\begin{array}{l}\text { Yaşam } \\
\text { Memnuniyeti }\end{array}$ \\
\hline Hane halkı Bütçe & Kümes Hayvancılığı & Tarımsal Fiyatlar & Yaygın Eğitim \\
\hline Hane halkı İșgücü & Mahalli İdare Çevre & Tarımsal Girdi & Yazılı Medya \\
\hline Hane halkı Turizm & Mali Aracı Kuruluș & Tarımsal İșgücü & Ylllı Sanayi Ürün \\
\hline İl Kamu Çevre & OFATS & Turizm & Yolcu Hareketliliği \\
\hline İș Kayıt Ana Faaliyet & OSB Çevre & TÜFE 2 4 Dönem & YSHİ Yatırım \\
\hline
\end{tabular}

Gönüllülük kavramının SUT uygulamalarında yüksek önem arz etmesi hasebi ile TÜIK İntranet Yönergesi Alanlar bölümünde, "İstatistik üreten ve saha çalışmaları üzerinden veri derlenen çalışmalar haricinde alan oluşturma isteğe bağlıdır. Ancak kişiler tarafından açılacak alanlar, alan uygulamaları için VTKD koordinasyonunda açılan alanlar ile aynı amaç ve kapsamda olamaz." maddesi eklenmiştir. Bu madde ile ortak ilgi alanlarına sahip çalışanların ortak çalışmalar yürütebilecekleri sanal ortamlar tesis edebilmelerinin önü açılmıştır.

İstatistik üreten ana hizmet birimleri tarafından oluşturulan 44 adet Alan haricinde kalan danışma, destek ve koordinasyon birimleri ile taşra teşkilatı birimleri tarafından açlan Alanlar da bulunmaktadır. Bunlardan bazıları Mali Konular Alanı, Elektronik Veri Transferi Alanı, Bursa Bölge Müdürlüğü Alanı ve Görevlendirme Uygulamaları Alanıdır. Nihai olarak TÜIKK İntranet içerisinde 2018 yılı Haziran ayı itibari ile toplam da 138 adet Alan (sanal uygulama topluluğu) oluşturulmuştur.

TÜIKK İntranet içerisinde en yoğun kullanılan Alan, İş Kayıtları Ana Faaliyet Araştırması (İKAFA) Alanıdır. İKAFA Alanına üye olan 211 çalışan tarafından, bu alan içerisinde bulunan forumda toplamda 670 adet ileti paylaşımı yapılmıştır (Bakınız Şekil 4.). Forum içerisinde yer alan sabit başlıklar VTKD tarafından tüm istatistik üreten birimleri ile görüşülerek oluşturulmuştur. 


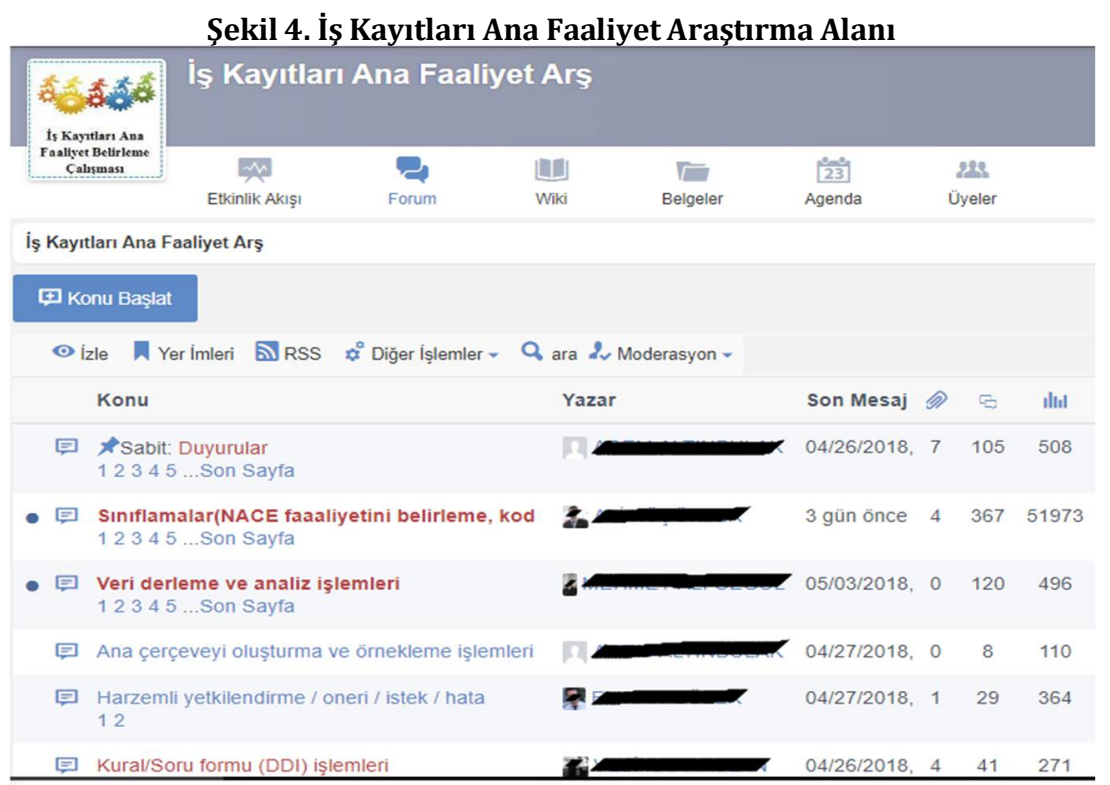

Şekil 4. de görüldüğü üzere İKAFA Alanı üst menüsünde etkinlik akıșı, forum, viki, belgeler ve takvim bölümleri yer almaktadır. Bu bölümlerin tamamına sadece bu alana üye olan kişiler tarafından erişim sağlanabilmektedir. Bunların yanı sıra Alan üyeleri İntranet içerisinde yer alan kişisel bildirimlerini açmaları durumunda Alan içerisinde yapılan paylaşımlardan e-posta ile de otomatik olarak haberdar edilmektedir.

Birbirinden farklı birimlerde ve şehirlerde çalışan kurum çalışanları oluşturulan bu sanal işbirliği ortamları sayesinde bir konu hakkında mütalaada bulunma, istişare etme, ortak dokümanlar üzerinde çalışabilme ve çalışma takvimleri belirleme imkânlarına kavuşmaktadır. Böylece benzer konular üzerinde çalışan kişiler arası etkileşim ve işbirliği etkin ve verimli bir biçimde tesis edilebilmektedir. E-posta grupları veya telefonlar üzerinden yapılan bilgi paylaşımlarında adeta akıp kaybolan kurumsal bilgiler yazılı hale getirilerek, konu bazlı tutulabilmekte ve nihai olarak kurumsal hafiza oluşumu sağlanmaktadır.

\subsubsection{TÜİK Forum}

TÜİK Forum, içerisinde genel ahlak kurallarına uygun olarak açılmış olan her türden konu başlığı altında bir sorunun veya konunun tüm çalışanlar önünde bütün ayrıntılarıyla tartışılacağı ve katılımcıların da bu tartışmanın içinde aktif olarak yer alacağı bölümdür. TÜIIK Forum, benzer forumların bir araya geldiği kategorilerden oluşur. TÜİK Forum içerisinde yeni forum açılması talepleri, kurum çalışanları tarafından her bir kategori içerisinde bulunan "Yeni Forum / Moderatör Değişikliği Talepleriniz" başlığı içerisinden yapılabilmektedir. Yeni forum talepleri İntranet Yardım Masası tarafından, İntranet İdari Yöneticisine iletilmektedir. İntranet İdari Yöneticisi tarafından uygun görülen (kategori uygunluğu, mükerrerlik kontrolü) forumlar, ilgili kategorilerde oluşturulmaktadır. 
TÜİK Forum içerisinde yeni açllan bir forumun moderatörü / moderatörleri, forum konusu ile ilgilisi doğrultusunda, TÜİK Görev Tanımları Rehberi esas alınarak İntranet Yardım Masası tarafından, Grup/Takım Sorumluları veya Müdürler (Bölge Müdürü hariç) arasından atanmaktadır. TÜİK Forum içerisinde yer alan bir foruma moderatör olarak atanan birim amirine, İntranet Yardım Masası tarafından, kendisinin hangi foruma moderatör olarak atandığı ve moderatör görevleri ile ilgili e-posta bildirimi yapılmaktadır. Birden fazla birimin kullandığı forumlarda (örneğin; iki ya da daha fazla birim tarafından ortak yürütülen çalışmalar için) ilgililer tarafından talep edilmesi halinde birden fazla moderatör, , İntranet Yardım Masası tarafından atanabilmektedir.

\subsubsection{TÜİK Viki}

TÜi̇K Viki genel olarak Kurum ile ilgili tanımlar ve ansiklopedik bilgileri içerecek olan bir bölümdür. Viki; mevcut bilgi ve belgelerin paylaşımı ve yeni kurumsal bilgi üretilmesi maksadı ile kullanılmaktadır. TÜİK Viki'nin amaç ve hedefleri yukarıda yer alan Tablo 3. içerisinde sergilenmiştir.

Tablo 3. TÜİK Viki'nin Amaç ve Hedefleri

\begin{tabular}{|l|}
\hline Amaçlar \\
\hline $\begin{array}{l}\text { e-Kurumsal hafızanın oluşturularak, esnek ve sürdürülebilir bir yapıda } \\
\text { geliştirilebilmesi, }\end{array}$ \\
\hline İç iletişimin arttırılması, \\
\hline Ortak dil ve yöntemler geliştirilebilmesi, \\
\hline Etkileșim halinde yeni bilgiler üretilebilmesi, \\
\hline Örgütsel ve bireysel öğrenmenin hızlandırılması \\
\hline Hedefler \\
\hline Kurumsal niteliğe ulașmıș bilgilerin paylașımı (rapor, kılavuz vb.) \\
\hline $\begin{array}{l}\text { Çalıșanlarımızın örtük (tecrübe) ve açık bilgilerinin (belge, kişisel not vb. yazılı) } \\
\text { paylaşımı ile yeni kurumsal bilgiler üretilmesi }\end{array}$ \\
\hline
\end{tabular}

Eski TÜIKK İntranet içerisinde yer alan belge ve dokümanlar T.C. Devlet Arşivleri Genel Müdürlüğü tarafından yayımlanan Standart Dosya Planı (SDP)'na göre tasnif edilerek Yeni İntranet içerisinde yer alan TÜİK Viki'ye aktarılmıştır (Detaylar için lütfen Şekil 5'e bakınız). 


\section{Şekil 5. TÜİK Viki}

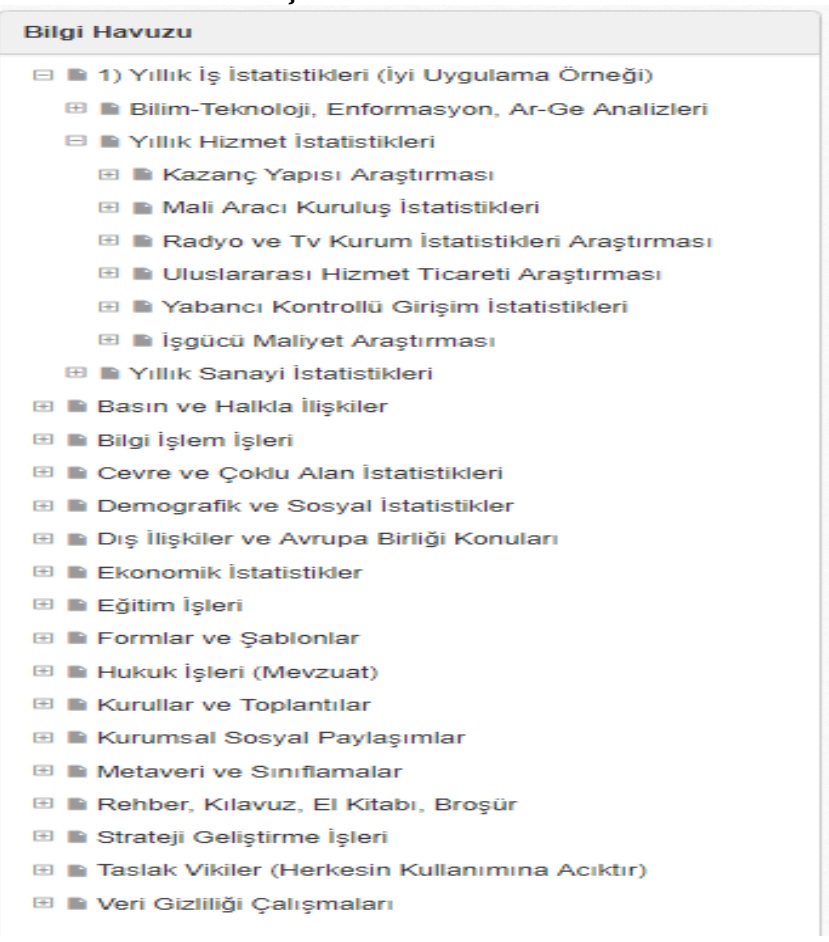

SDP’ye göre oluşturulan başlıklar sabit olup, bu başlıkların içerik yönetimi ilgileri doğrultusunda TÜİK birimleri tarafından yapılmaktadır. Birimlerin yetkilendirmeleri İntranet Yardım Masası tarafından kişi bazında değil birim bazından yapılmaktadır. Olușturulan bir vikinin kimin tarafından görülebileceği, değiștirilebileceği vb. işlevler yetkilendirme mekanizması içinde bulunmaktadır.

TÜIKK Viki içerisinde "Kurumsal Sosyal Paylaşımlar" ve "Taslak Vikiler" başlıkları Kurum çalışanlarının bireysel katkı sunumuna açıktır. İlgili başlıklarda tüm çalışanların içerik okuma ve ekleme yetkileri bulunacak ancak diğer çalışanlar tarafından oluşturulan içeriği değiştirme veya silme yetkileri bulunmamaktadır. TÜİK Viki ve birim bilgi havuzları haricinde, her çalıșanın kendisine ait "kișisel vikisi de bulunmaktadır. Bu vikiler varsayılan ayar olarak sadece vikiyi oluşturan kişi tarafından görülebilmektedir, ancak kişiler isterse bireysel vikilerini diğer çalıșanların erişimlerine de açabilme yetkilerine sahiptir.

\subsubsection{Belgeler}

Belgeler bölümü mevcut durumda Kurum içerisinde "ortak alan" olarak adlandırılan sunucular içerisinde bulunan belge ve dokümanlardan arşiv niteliğine sahip olanların İntranet içerisine aktarılması neticesinde oluşturulan bölümdür. Her birim için İntranet sistemi tarafından otomatik olarak bir Belgeler bölümü açılmaktadır. Birim çalışanları, İnsan Kaynakları Sistemi ile bütünleşik olarak çalışan İntranet sistemi tarafından otomatik olarak kendi birimlerine ait Belgeler bölümüne erişebilmektedir. 
Bunların yanı sıra birimlere ait Belgeler bölümü içerisinde paylaşılacak klasör ve dosya isimleri belirlenirken TÜİK Faaliyet, Ürün ve Hizmet Sınıflaması (TÜİK FÜHS) dokümanı esas alınmaktadır. TÜİK İntranet Yönergesine eklenen bir madde ile Belgeler bölümü içerisine, veri tabanlarında yer alması gereken, hacimli veri setleri bulan veri dosyalarının atılması yasaklanmıştır.

\subsubsection{Kurum İçi Geliştirilen Yazılımlar 3.3.5.1. Kurum İçi Duyurular Uygulaması}

TÜİK İntranet öncesinde kurum içi duyurular, Basın ve Halkla İlişkiler Müşavirliği (BHIM) çalışanları tarafından yapılmakta idi. BHIM duyuru sorumlusu tarafından diğer birim veya kişilerden gelen kurum içi duyuru talepleri incelenir ve bu içerik kontrol sonrasında tüm kurum çalışanlarının üye olduğu bir e-posta grubuna gönderilirdi. Dolayısı ile kurumsal duyuruların yapılmasında kişiye ve birime bağımlık söz konusu olmakta, bu nedenle kimi zaman acil duyuruların yapılması zaman alabilmekteydi.

TÜIK'te, 2017 yllından itibaren kurum içi duyurular yeni İntranet bünyesinde oluşturulan "Duyuru Alanı" içerisinde yer alan bir duyuru yazılım uygulaması ile yapılmaya başlanmıştır. Birimler, kurum içi duyuru sorumlularını bir defaya mahsus olmak üzere BHIM'e bildirmektedir. BHIM tarafından Duyuru Alanı'na üye yapılan kișiler, Birim Duyuru Sorumlusu olmaktadır. Birim Duyuru Sorumluları, birimleri adına duyuru yapma ve duyuru düzenleme yetkilerine sahip olmaktadır.

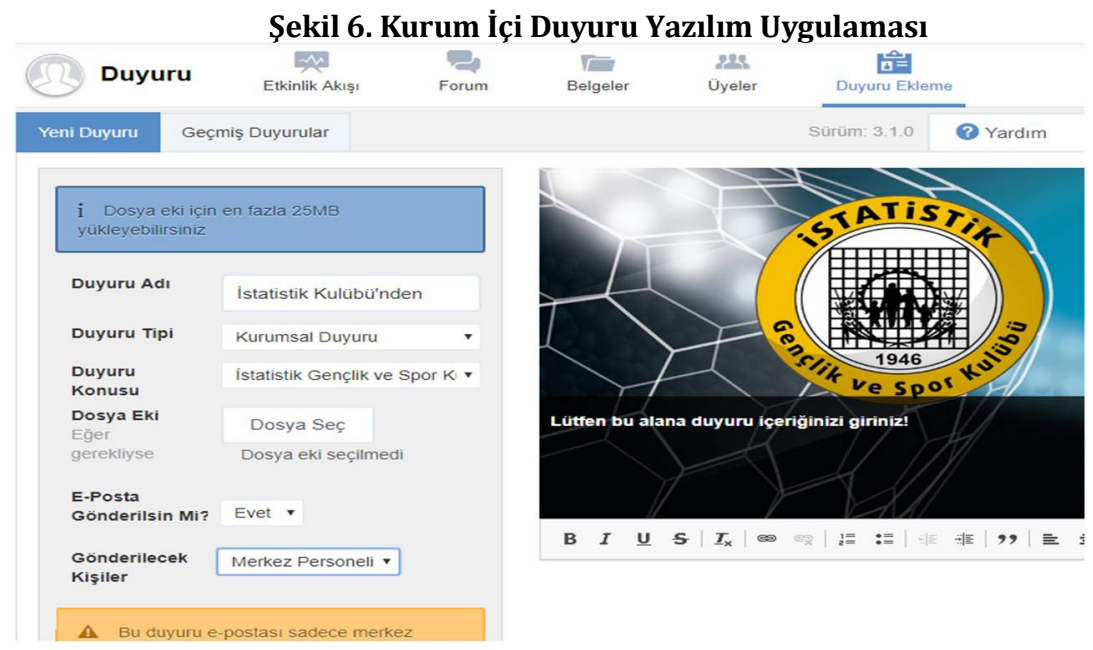

Duyuruların yapılması, Șekil 6. içerisinde yer alan yazılım uygulaması ara yüzü sol kısmında görüldüğü üzere duyuru adı, duyuru tipi (kurumsal duyuru ise 1 gün, Viki duyurusu ise 30 gün yayın), dosya eki (varsa), e-posta gönderme (Tüm personel, Merkez Teşkilatı, Taşra Teşkilatları) gibi seçenekler barındırmaktadır. Viki ve kurumsal duyuru tipleri ile ilgili detaylı bilgiler Tablo 4. içerisinde sergilenmiştir. 
Tablo 4. Kurum İçi Duyuru Tipleri

\begin{tabular}{|l|l|}
\hline Kurumsal Duyuru Tipleri & Viki Duyuru Tipleri \\
\hline$\bullet \quad$ Bayramlașma & $\bullet$ Genel Koordinasyon Tutanağı \\
\hline$\bullet \quad$ Etik bilinci hatırlatma & $\bullet$ Üst Yönetim Toplantı Tutanağı \\
\hline$\bullet \quad$ Genel ilaçlama & $\bullet$ Gazete TÜİK \\
\hline$\bullet \quad$ Genel temizlik & $\bullet$ Medya Analiz Raporları \\
\hline • İstatistik ve Gençlik Spor Kulübü & $\bullet$ Diğer \\
\hline • Kan ihtiyacı & \\
\hline • Sistem bakımı & \\
\hline • Vefat ve bașsağlı̆ı & \\
\hline • Yurtdıșı faaliyet sunumu & \\
\hline
\end{tabular}

Bu uygulamanın kullanım usul ve esasları ise TÜİK İntranet Yönergesi içerisinde belirtilmiştir. Yönergeye göre, kurum içi duyuruların tamamı "Duyuru Yönetimi Alanı" içerisinden yapılacaktır. Bu duyurular, İntranet ana sayfa bölümünde "Duyurular" başlığı altında, görünür bir yerde bulunacaktır. $\mathrm{Bu}$ alanın yönetiminden BHIM sorumludur. Yönerge içerisinde ayrıca duyurular bölümüne yeni bir yükleme yapıldığında, ara yüz içerisinde talep edilmesi durumunda İntranet sistemi tarafından otomatik olarak tüm TÜİK çalıșanlarına, bu paylașımın e-posta bildirimi yapılacağına dair bir madde de eklenmiștir.

\subsubsection{Sık Kullanılanlar Uygulaması}

İntranet platformunda, sağ üst köşede "Sık Kullanılanlar" adında ayrı bir yazılım uygulaması yer almaktadır (Bakınız Şekil 3.). Sık kullanılanlar bölümünde uygulama linkleri (Telefon Defteri, Karar ve Mevzuat İzleme Sistemi, Kütüphane, TÜİK e-posta gibi ) yer almaktadır (Bakınız Şekil 7).

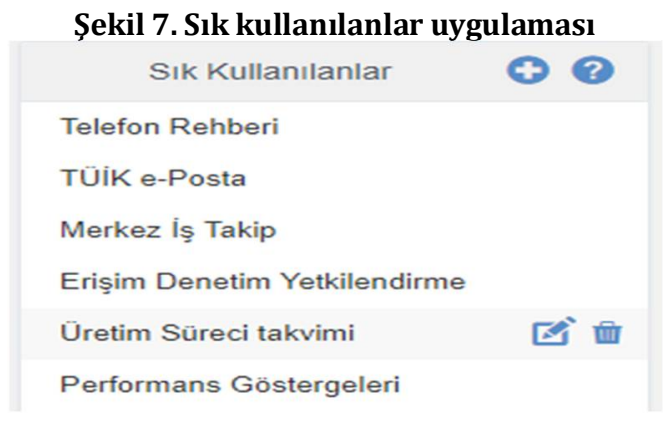

Kişiselleştirilebilir yapıda olan Sık Kullanılanlar uygulaması ile çalıșanlar kendi sayfalarına istedikleri uygulama linklerini ekleme, düzenleme veya kaldırma yetkilerine sahiptir. Ayrıca Sık Kullanılanlar uygulamasının sürükle bırak özelliği ile sık kullanılanlar listesinde yer alan uygulamaların yerleri de değiștirilebilmektedir.

\subsubsection{Erişim Denetimi Uygulaması}

Erişim Denetimi (ED), kurum içerisinde kullanılan tüm rol bazlı yazılım uygulamaları için geliştirilen, hiyerarşik rol tabanlı yetkilendirme uygulamasıdır. İnsan 
kaynakları yazılımları, elektronik belge yönetim sistemi, yemek sipariş, bilişim teknik destek, İstatistiksel veri toplama, araç takip, bütçe kontrol bu yazılımlardan bazılarıdır.

ED içerisinde yer alan ve insan kaynakları veri tabanından beslenen kurumsal hiyerarşi bilgileri sayesinde, üstteki bir birim alttaki birim/birimlerin sahip olduğu rollere otomatik olarak sahip olmaktadır. Diğer yandan amirlere ait kurum içi yazılım programlarına erişim yetkileri, amirlerin izinli oldukları dönemde vekâlet bıraktıkları kişilere ED uygulaması tarafından otomatik olarak devredilebilmektedir. Amirin göreve başlaması ile birlikte ED uygulaması ile astların geçici erişim yetkileri geri alınmaktadır. Bunların yanı sıra amirler, yetki devri kapsamında da bir takım yetkilerini rol bazlı olarak astlara ED vasıtası ile aktarabilmektedir. Sistemde, kullanıcılara bir veya birden fazla rol atanabilir. Kullanıcılar sahip oldukları bu rollere göre kurum içerisindeki yazılım uygulamalarındaki yetkiler ile ișlemler gerçekleștirebilirler.

Eski İntranet içerisinde çalışanların ilave bir şifre girişi ile giriş yapabildikleri ED uygulamalarına, Yeni İntranet içerisinde gerçekleștirilen kimlik doğrulama işlevi sayesinde şifresiz erişim imkânı sunulmuştur. Böylece çalışanlar, İntranet sistemine giriş yaptıklarında, ana sayfa içerisinde yetkili oldukları uygulamalara doğrudan erișebilme imkânına kavuşmuştur.

\subsection{TÜİK İntraneti Bașarılı Kılan Unsurlar 3.4.1. Üst Yönetim Desteği}

TÜíK İntranet projesinin başarılı bir biçimde hayata geçirilmesinde Kurum Üst Yönetimi'nin desteği büyük önem arz etmiștir. Özellikle Yeni İntranet Platformunun kullanıma alındığı 2017 Ocak ayını takip eden Mart ayında gerçekleştirilen Genel Koordinasyon Toplantısında alınan GKT - 2105 kararı adeta bir devrim niteliğinde olmuştur. Bu karara binaen Merkez ve Taşra birimleri arasında yürütülen ortak çalışmalarda temel bilgi paylaşım platformu olarak kullanılan e-posta gruplarının kapatılarak, bilgi paylaşımlarının İntranet Alanlar bölümü içerisinden yapılması kararlaștırılmıștır.

İlgili GKT'da, 2105 nolu kararın alınabilmesinde İntranet proje yöneticisinin sunumu etkili olmuştur. Bu sunum kapsamında, Alanlar (sanal uygulama toplulukları) bölümü ile Merkez-Bölge, Merkez-Merkez, Bölge-Bölge arasındaki iletişimini nasıl verimli ve etkin bir hale getirebileceğinden bahsedilmiștir. Mevcut durumda kullanılan iletişim araçlarından e-posta grupları ve telefon üzerinden gerçekleştirilen iletişim neticesinde yazılı kurumsal hafıza oluşturulamaması sorununa değinilmiştir. İlave olarak benzer soruların farklı çalışanlar tarafından mükerreren ilgililere sorulması ve mükerreren cevaplanmasının iletişim yükünü artırdığına vurgu yapılmıştır. Bu iletişim araçları yerine bilgi paylaşımların kümülatif olarak birikmesine olanak sağlayan, forum ve viki gibi elektronik platformların kullanılmasının gerektiği belirtilmiştir. İntranet proje yöneticisi tarafından yapılan sunum akabinde GKT - 2105 kararı alınmıştır. İntranet proje yöneticisinin gayretleri esas itibari ile projeden sorumlu olan kișilerin katkılarının da en az üst yönetim desteği kadar ehemmiyet taşıdığına işaret etmektedir.

\subsection{2. İntranet'in Orkestrasyonu}

İntranet platformlarının tamamında kimin nereye, ne şekilde ve hangi yetkilerle erișebileceklerinin belirtildiği usul ve esasların belirlenmesi ve takibinin yapılması öncelikli önem arz etmektedir. Bunların yanı sıra kurum içi kullanıcı eğitimlerinin verilmesi, ihtiyaç duyulan yeni yazılım gereksinimlerin belirlenmesi ve geliștirilmesi, genel içerik yönetiminin yapılması ve son kullanıcı taleplerinin karşılanması gibi 
birbirinden farklı birçok hususun idare edilebilmesi ancak salt olarak bu işler için tahsis edilen yetkin bir ekip ile gerçekleştirilebilir.

$\mathrm{Bu}$ doğrultuda TÜIKK İntranet Yönergesi içerisine 4 bentten oluşan Roller ve Yetkilendirme Hususlarına iliş̧in Uygulama Esasları adında bir madde eklenmiștir. Bu madde içerisinde İntranet proje ekibinde yer alacak İntranet proje yöneticisi, yazılım uzmanı, iş analisti ve intranet yardım masası rollerine dair nitelik gereksinimleri ve yetkiler belirtilmiştir.

İntranet Proje Sorumlusu intranetin teknik alt yapı, yurt dışı danışmanlık hizmeti temini, İntranet yönergesinin hazırlanması, iş akış şemasının tesis edilmesi ve iş süreçlerinin takibi, yeni yazılım önerilerinin değerlendirilmesi ve planlanması, içerik yönetiminin yönetilmesi, yapılması gereken ișlerin belirlenmesi ve proje takip sistemine girilmesi gibi birbirinden farklı hususlar ile ilgilenmektedir. Bunların yanı sıra İntranet proje yöneticisi tarafından son kullanıcılara yönelik İntranet ile ilgili bilgilendirici içerikler hazırlanması gibi faaliyetler de yürütülmektedir. Bu faaliyetlere örnek olarak İntranet proje yöneticisi tarafından hazırlanan içeriklerden bir kaç tanesi aşağıda paylaşılmıştır.

"Bilgi paylașımı yapmak için FORUM mu, yoksa VIKİ mi kullanmalıyım?

Forum içerisinde açılan konularda genel olarak ilk etapta henüz olgunlaşmamış hususlar yer alır. Kullanıclları yazmaya teşvik edici sorular (productive inquiry) sorularak belirli bir hususta birçok kişinin katkısı ile bilgi toplanmaya ve olgunlaşmaya başlar. Bilginin olgunlaşması süreci, mutfak misali hangi malzemenin (bilgi), nereden, nasıl, ne zaman ve kim tarafından katılacağına bağlı olarak değişim gösterecektir. Belirli bir seviyede olgunlaşan bilgi artık sunuma hazırdır, yani vikiye konulabilir. Vikiye ulaşan bilgilerde de elbette zaman içerisinde değişiklikler yapılabilir ancak bunun boyutu foruma göre oldukça düşüktür."

\section{Şekil 8. Kişisel bilgilerin yazılı kurumsal hafızaya dönüşüm süreci}

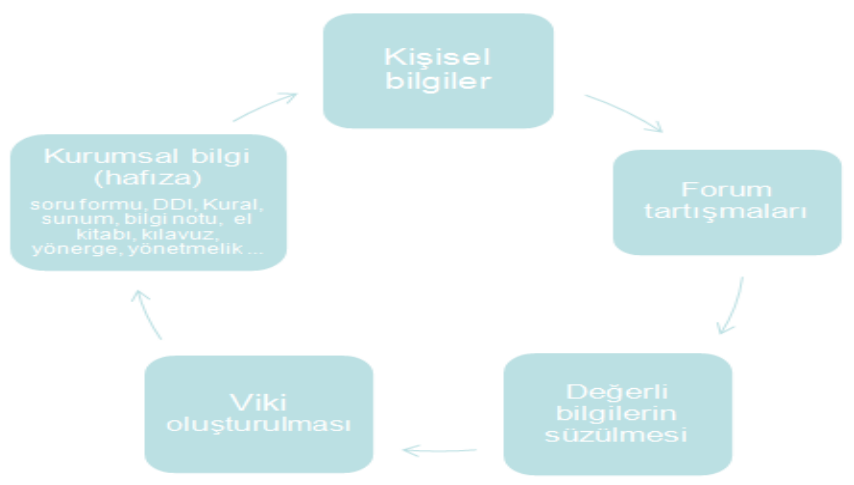

"Yukarıda yer alan şekilde de belirtildiği üzere, ne vakit bizler forumda tartışılan bilgilerden viki üretir, ürettiğimiz vikilerden de kullanım kılavuzları, yönergeler, el kitapları, iç genelgeler vb. ürünleri çıkarabilirsek, o vakit yazılı kurumsal hafiza sahibi bir Kurum olabiliriz. Bunu başarabilmek için elimizde maddi imkânların yanı sıra teknik imkânlar ve kaliteli insan kaynağı da dâhil tüm kaynakların olduğu düşüncesindeyim. İyi çalışmalar, Intranet Proje Yöneticisi."

İntranet'in orkestrasyonunun özel bir ekip tarafından yürütülmesi İntranet projesinin başarısını yüksek oranda etkilemiștir. 


\subsubsection{Bilimsel Araştırmalar}

TÜİK İntranet projesinin muvaffak olabilmesi için bir yıldan fazla süren akademik araştırmalar yürütülmüștür [7]. Bu kapsamda gerçekleştirilen araştırma bulgularına binaen, dört boyutlu (nitel, nicel, bireysel, kurumsal) TÜİK Bilgi Paylaşım Haritası çıkarılmıştır. TÜİK'te elektronik bilgi paylaşımını etkileyen faktörlerin belirlenmesinin akabinde, bu faktörler göz önünde bulundurularak TÜIK İntranet Kullanımı Usul ve Esasları Hakkında Yönerge oluşturulmuştur. Bu yönerge gerek kapsam genişliği gerek ise içerik derinliği açısından diğer örgütlere yol gösterici olabilecek mahiyette bir çalışma olmuştur.

\subsubsection{Mevzuat Düzenlemesi}

İntranet yönergesinin Kurum Bașkanlığı tarafindan imzalanarak, resmi belge niteliğine dönüșmesi ile üst yönetim desteği tescillenmiștir. İntranet pilot uygulama evresi olan 2015-2016 yılları arasında gerçekleștirilen bilimsel akademik çalıșmalar neticesinde (Metin ve Medeni, 2016) elde edilen bulgular göz önünde bulundurularak teferruatlı bir biçimde hazırlanan ve dokuz sayfadan oluşan TÜİK İntranet Kullanımı Usul ve Esaslarına Yönelik Yönergesi, Mart 2017 tarihinde Kurum Başkanlığı tarafından onaylanarak yürürlüğe girmiștir.

\subsubsection{Son Kullanıcı Eğitimi ve Destek}

Merkez teşkilatında her birimden bir kişiye kurum içerisinde yer alan bilgisayarlı eğitim merkezinde yüz yüze ve 26 bölge müdürlüğü personeline video konferans sistemi ile TÜİK İntranet'in kullanımı ile ilgili uzaktan eğitim verilmiştir. Gerçekleştirilen eğitimlerde İntranet kavramının tanımı, Yeni TÜİK İntranet'in sunabileceği e-işbirliği, eiletişim, kültürel dönüșüm imkânlarına vurgu yapılmıș, İntranet'te yer alan forum, viki, belgeler, kişiler ve uygulamalar gibi bölümlere ait mevcut iyi uygulama örnekleri incelenmiștir.

Bunların yanı sıra İntranet ana sayfa sol üst bölümde yer alan Yardım Masası bölümünde oluşturulan forumlar vesilesi ile son kullanıcı talepleri şeffaf bir biçimde takip edilebilmektedir. Yardım masası forumları içerisinde son kullanıcılardan yeni bir talep geldiğinde İntranet yardım masası çalışanlarına otomatik olarak e-posta bilgilendirmesi gönderilmektedir. İntranet yardım masası tarafından incelenen talepler proje takip sistemi üzerinden iş analisti'ne aktarılmaktadır. İș analisti ve yazılım uzmanlarınca üretilen çözümler, Yardım masası forumları üzerinden son kullanıcılarla paylaşılmaktadır.

Son kullanıcı taleplerinin şeffaf bir biçimde forumlar üzerinden yönetilmesi vesilesi ile bir soruya yönelik verilen bir cevap tüm kurum çalışanlarınca görülebilmektedir. Netice olarak yardım masası üzerindeki cevaplayıcı yükü 2017 yılı içerisinde zaman içerisinde günlük ortalama 20 talep düzeyinden, bir ila iki talep düzeyine kadar inmiştir (Detaylar için lütfen Şekil 9.'a bakınız). Bu azalmada kullanıcıların TÜİK İntranet platformunu kullanımına zamanla aşina hale gelmeleri de etkili olmuş olabilir. 


\section{Şekil 9. İntranet Kullanıcı Sorunları Forumu}

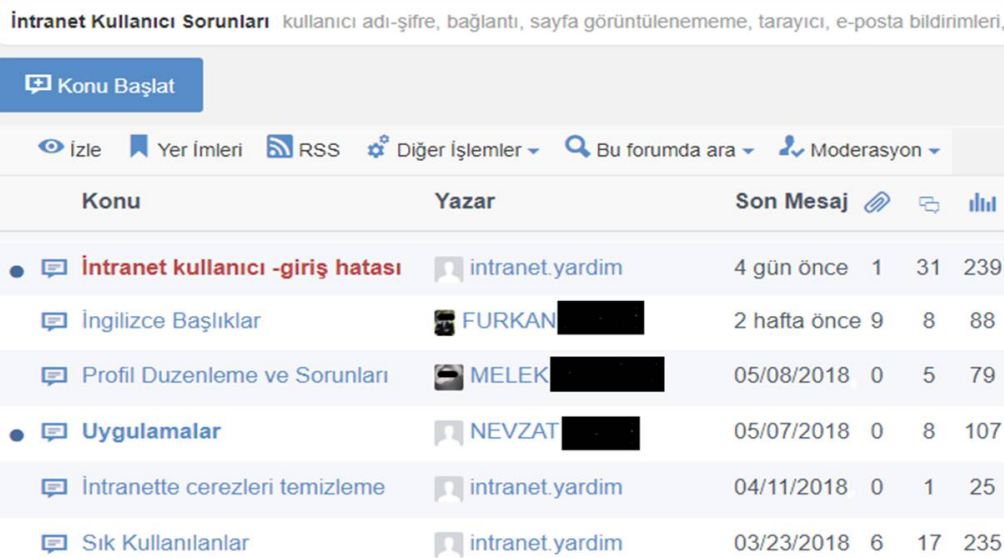

Lakin Şekil 9. içerisinde sağ kısımda yer alan paylaşım ve görüntülenme rakamları incelendiğinde, görüntülenme rakamlarının, paylaşım rakamlarının ortalama on katı olduğu görülmektedir. Bu oran, İntranet içerisinde sorulan bir soru mukabilinde verilen cevabın on farklı kullanıcı tarafından görüntülenmekte olduğunun göstergesidir. $\mathrm{Bu}$ durum sanal ortamda gerçekleştirilen şeffaf bilgi paylaşımlarının cevaplayıcı yükünü mühim bir ölçüde azalttığının bariz bir örneğidir.

\section{Tartışma ve Sonuç}

$\mathrm{Bu}$ çalıșmada Dördüncü Endüstri Devriminin olgunlaşttğı bu yıllarda dünya genelinde ve Türkiye'de İnternet kullanımında yașanan artış konusuna değinilmiş ve çalışma ortamında yaşanan dijital dönüşüm konusu İntranet platformları üzerinden ele alınmıştır. $\mathrm{Bu}$ bağlamda öncelikle günümüz dijital çalışma ortamı koşullarını sağlayamayan geleneksel İntranet platformlarının kısıtları irdelenmiştir. Daha sonra yeni nesil dijital İntranet platformlarının örgütler için özellikle kamu örgütleri için ne denli elzem olduğu vurgulanmıștır. Bu önemim vurgulanmasının akabinde ise geleneksel İntranet sistemlerinden dijital İntranet sistemlerine geçiş için dünya genelinde yaygın kullanılan açık ve kapalı kaynak kodlu dijital İntranet platformlarının mukayeseleri yapılmıştır. $\mathrm{Bu}$ çalışmanın son bölümünde ise TÜİK İntranet sistemlerinde dijital dönüşüm projesini başarılı kılan unsurlar detaylı bir biçimde ele alınmıştır.

Üst yönetim desteği, İntranet proje ekibinin oluşturulması, yıllara sari proje bütçesinin oluşturulması, kurum içi bilgi paylaşımını etkileyen faktörlerin belirlenmesi, İntranet yönergesinin oluşturulması, kullanıcı eğitimleri ve kurum içi diğer yazılımlar sistemleri ile entegrasyon gibi faktörlerin tamamı TÜİK İntranet Projesinin hayata geçirilmesinde önemli rol oynamıștır. Özellikle geleneksel İntranet sistemlerinde var olmayan şeffaf, dijital örgüt içi bilgi paylaşım kültürünün sanal uygulama topluluğu (SUT) yöntemleri ile nasıl tesis edilebileceği de bu çalışma içerisinde ayrıca ele alınmıştır.

Bir önceki paragraf içerisinde bahsedilen ve TÜİK İntranet Projesini başarılı bir SUT platformuna dönüştüren faktörlerin yanı sıra, sanal işbirliği yaklaşımlarının olmazsa olmaz unsuru olan esnek çalıșma koşullarının da yasal alt yapısının ülkemizde oluşturulması gerekmektedir. Bilgi Toplumu Stratejisi ve Eylem Planı (Kalkınma Bakanlığı, 2014) içerisinde bahsedildiği üzere $A B$ ülkeleri ile mukayese edildiğinde 
Türkiye'de esnek çalışma konusunda sınırlı sayıda düzenlemeye rastlanılmaktadır. Bu düzenlemelerden bir tanesi 2016 yılında yasalaşan 4857 Sayılı İş Kanunu ile işçi ve işverenlerin çalışma saatlerini belirli ölçülerde kendi inisiyatifleri doğrultusunda belirleme imkânı tanıyan geçici iş ilişkisi, kısmı süreli çalışma, çağrı üzerine çalışma, denkleștirme süresi, telafi çalıșması ve serbest zaman gibi hususlarda esnekliği artıcı düzenlemeler hayata geçirilmiştir. Lakin ilgili kanun sadece özel sektöre yönelik olmakla birlikte, gerek işçilerin gerekse işverenlerin ilgili yasal düzenlemeye yönelik bilgileri sınırlı kalmaktadır (Koç, 2016). Özellikle kamu sektöründe esnek çalışma imkânı neredeyse bulunmamaktadır. Güvenlik politikaları öne sürülerek, çalışanların VPN gibi özel bağlantılar ile kurumsal ağlara (LAN, VLAN) erişimlerine izin verilmemektedir. Bu durum çalışanların aynı fiziksel ortamlarda, geleneksel çalışma saatlerinde 008:00-17:00 gibi) bir arada bulunmalarını zorunlu kılmaktadır. Netice olarak özellikle kamu örgütlerinde SUT oluşturulması ve sanal işbirliği imkânları oldukça kısıtlı kalmaktadır.

TÜIK İntranet sisteminde oluşturulan SUT (Alanlar/Spaces) sayesinde ise kurum çalışanları arasında yer ve zamandan bağımsız olarak işbirliği tesis edilebilmesinin önü açılmıştır. Bu vesile ile telefon, e-posta ve yüz yüze görüşme gibi iletişim yöntemleri asgari düzeye çekilmiş ve iletişim maliyetleri düşürülmüş, iş süreçleri daha etkin hale gelmiştir. Bunların yanı sıra Alanlar içerisinde yer alan forum, viki ve belgeler gibi bölümlerde gerçekleştirilen konu bazlı bilgi paylaşımları sayesinde yazılı kurumsal hafıza oluşumunun temelleri atılmıştır. Kurum çalışanları tarafından TÜİK Viki içerisinde 641 adet viki sayfası oluşturulmuştur. TÜİK İntranet sisteminde gerçekleştirilen bu dijital dönüşüm diğer kamu ve özel sektör örgütleri için de ilham verici mahiyettedir.

\section{KAYNAKÇA}

AZİZ, A., DİCLE, Ü. (2017). Örgütsel iletişim. İstanbul: Hiperlink Yayınları. ÇEKIÇ, E. \& ÜSTÜNDAĞ, M.T. (2016). İntranet-tabanlı bilişim teknolojileri servis yönetimi uygulaması. Bilișim Teknolojileri Dergisi, 9 (3), 303-314.

DUBE, L., BOURHIS, A. \& JACOB, R. (2006). Towards a typology of virtual communities of practice. Interdisciplinary Journal of Information, Knowledge, and Management, 1, 69-93.

ERBAY, H. \& KÖR, H. (2016). Büyük veri ve büyük verinin analizi. Uluslararası Bilim ve Teknoloji Konferansı, YTSAM, Ankara, 3-6 Ekim.

eXo Platform Editions and Pricing (2018). Compare plans. Erişim tarihi: 06.05.2018, https://www.exoplatform.com/pricing.

FARAJ, S., KUDARAVALLI, S., \& WASKO, M. (2015). Leading collaboration in online communities. MIS Quarterly, 39 (2), 393-412.

HITCHINS, S. (2014). The hidden cost of SharePoint. Erişim tarihi: 06.05.2018, https://www.interact-intranet.com/blog/the-hidden-costs-of-sharepoint.

JOHNS, T. \& GRATTON, L. (2013). The third wave of virtual work. Harward Business Review, 91 (1-2), 66-73.

2018. Ankara.

KALKINMA BAKANLIĞI (2014). Bilgi Toplumu Stratejisi ve Eylem Planı 2014-

KOÇ, M. (2016). 4857 Sayılı İș Kanunundaki Esneklik Düzenlemeleri Ve

Uygulama Problemleri, Insan ve Toplum Bilimleri Araştırmaları Dergisi, 5 (7), 2169-2192.

LAVE, J., WENGER, E. (1991). Situated learning: legitimate peripheral participation. Cambridge: Cambridge University Press.

MEISTER, J. C., WILLYERD, K. (2010). The 2020 workplace: how innovative companies attract, develop, and keep tomorrow's employees today. New York: Collins Business. 
METIN, F. \& MEDENI, T.D. (2016). Measuring Organisational Readiness for Successful Online Knowledge Sharing. ADAM Akademi Sosyal Bilimler Dergisi, , 6 (1), 129155. 96-104.

NONAKA, I. (1991). The knowledge-creating company. Harvard Business Review,

SAINT-ONGE, H., WALLACE, D. (2003). Leveraging communities of practice for strategic advantage. Amsterdam: Butterworth-Heinemann.

TÜİK. (2018). Hanehalkı bilișim teknolojileri (BT) kullanım araştırması, 2018. Erişim tarihi: 06.05.2018, http://www.tuik.gov.tr/PreHaberBultenleri.do?id=27819.

WATERFORD TECHNOLOGIES (2017). Big data statistics \& facts for 2017. Erişim tarihi: 06.05.2018, https://www.waterfordtechnologies.com/big-data-interesting-facts/.

\section{Summary}

The nature of workplace has been reshaped radically by technology during the last decade which in turn has created a new virtual world of online collaboration. The contemporary virtual working platforms (digital Intranets) have allowed organisations to team employees with different departments or geographic locations upon same projects or virtual communities. Additionally, the employees are able to exchange and create new organisational knowledge through exchanging information and experience. Nevertheless most of the organisations have been unable to experience these changes, particularly public organisations. Is knowledge considered as a valuable asset in public sector? Most of the answers of top public managers would be yes to this question; however it is quite rare to see a public organisation with collaborative digital knowledge repositories used efficiently and effectively. Both the knowledge in unwritten formats such as individual's memories and also the knowledge in written forms are locked up in personal computers such as fact sheets, reports and presentations, are disappeared in a case of employee turnover. In this case study, the need of contemporary digital Intranet systems with virtual communities of practices in order to have an effective organisational e-collaboration in today's highly virtualisation on working life is underlined.

In this regard, the Intranet revaluation of Turkish Statistical Institute, which is one of the first public institutions about identifying the need of e-transformation in the work life, between the years 2012 and 2017 will be investigated in details. Meanwhile, how several beneficial outcomes obtained such as (a) enabling e-collaboration among employees regardless of their location and department, (b) decreasing the cost of organisational communication, (c) integrating organisational software applications and, (d) laying the foundation of participative written organisational memory, will be further explained in this article. In this article the qualitative research approach was adopted and the data collected by observation, interview and document collection techniques. This paper is one of the first studies in which organisational e-collaboration and virtual communities of practice approaches were implemented in a Turkish public sector organisation. In fact, a better understanding of both the necessity and the requirements of establishing an efficient digital Intranet system may be beneficial for public sector organisations, particularly for those which have a considerable number of units and/or regional offices. Nevertheless it should be noted that since each organisation has different internal environments such as management styles, employees, structure and budgets etc., the digital Intranet solutions may also differ among the organisations. 